\title{
Uncertainty profiles in engineering-service development: Exploring supplier co- creation
}

\author{
Ramirez Hernandez, Tabea; Kreye, Melanie
}

Published in:

Journal of Service Management

Link to article, DOI:

10.1108/JOSM-08-2019-0270

Publication date:

2021

Document Version

Peer reviewed version

Link back to DTU Orbit

Citation (APA):

Ramirez Hernandez, T., \& Kreye, M. (2021). Uncertainty profiles in engineering-service development: Exploring supplier co-creation. Journal of Service Management, 32(3), 407-437. https://doi.org/10.1108/JOSM-08-20190270

\section{General rights}

Copyright and moral rights for the publications made accessible in the public portal are retained by the authors and/or other copyright owners and it is a condition of accessing publications that users recognise and abide by the legal requirements associated with these rights.

- Users may download and print one copy of any publication from the public portal for the purpose of private study or research.

- You may not further distribute the material or use it for any profit-making activity or commercial gain

- You may freely distribute the URL identifying the publication in the public portal

If you believe that this document breaches copyright please contact us providing details, and we will remove access to the work immediately and investigate your claim 


\section{Title Page}

Title: Uncertainty profiles in engineering-service development: Exploring supplier cocreation

\section{Author Details:}

Author 1 Name: Tabea Ramírez Hernández

Department: Management Engineering

University/Institution: Technical University of Denmark

Town/City: Lyngby

Country: Denmark

Author 2 Name: Melanie E. Kreye

Department: Management Engineering

University/Institution: Technical University of Denmark

Town/City: Lyngby

Country: Denmark

Corresponding author: Tabea Ramírez Hernández

Corresponding Author's Email: tarah@dtu.dk

\section{Please reference as:}

Ramirez Hernandez, T. and Kreye, M. E. (forthcoming) 'Uncertainty profiles in engineeringservice development: Exploring supplier co-creation', Journal of Service Management 


\title{
UNCERTAINTY PROFILES IN ENGINEERING-SERVICE DEVELOPMENT: EXPLORING SUPPLIER CO-CREATION
}

\begin{abstract}
Purpose: Engineering-service (ES) development, particularly with supplier co-creation, is nontrivial, and the literature has acknowledged the high relevance of uncertainty in this context. This study investigates the relationship between different supplier co-creation modes (operationally independent [OI] and operationally dependent [OD]) and uncertainty criticality arising during ES development.

Design/Methodology/Approach: This study develops a conceptual framework of five uncertainty types by synthesizing the relevant literature from service management and new product development. This framework guided the empirical work of two in-depth case studies, describing uncertainty criticality in OI and OD supplier co-creation.

Findings: The findings show that environmental and organizational uncertainty were generally of high criticality for ES development independently of the supplier co-creation mode. Moreover, uncertainty criticality varied between the two cases, with higher criticality of technical and relational uncertainty as well as less resource uncertainty experienced by the focal organization in the OD case. This suggests that supplier co-creation constitutes an uncertainty reallocation.

Research Limitations/Implications: Further research is needed to test the generalizability of the qualitative results through quantitative studies.

Originality/Value: This research contributes to the service management literature by showing the varying uncertainty profiles manufacturing organizations face when engaging in different supplier co-creation modes. Furthermore, this research provides novel insights on ES development to the broader discussion on ES management.
\end{abstract}

Keywords: Servitization; uncertainty management; engineering service; engineering-service development; co-creation 


\section{Introduction}

Uncertainty, defined as a lack of understanding (Kreye et al., 2012), is a key concern when engaging in engineering services (ES). ES are a subset of professional services and apply engineering knowledge such as technologies, skills, and expertise to solve knowledge-intensive problems for asset-heavy customers (Zhang et al., 2016). The long-term performance during ES provision is strongly impacted by the development of these offerings (Kindström and Kowalkowski, 2009), and requires balancing many different demands by the manufacturer. One central concern is uncertainty criticality, which refers to the differing potential impact of uncertainty on the development project (Erkoyuncu et al., 2014). For example, uncertainty in ES development can arise from its strong difference from traditional product development (Nordin et al., 2011). In ES development, manufacturers encounter high process complexity, which causes a lack of understanding because of the need to integrate product and service elements (Gebauer et al., 2017). Moreover, uncertainty can arise because ES development requires manufacturers to manage the intricacy of two differing business logics (product and service) in parallel ( $\mathrm{Ng}$ et al., 2012). These and further examples, leave manufacturers with a general lack of understanding of ES development.

Many manufacturers attempt to solve this problem by sourcing the required capability through engaging in supplier co-creation during the ES development (Oertzen et al., 2018). Originally investigated in the context of new product development (NPD; (Prahalad and Ramaswamy, 2004; Hoyer et al., 2010; Lee and Schmidt, 2017), the importance of co-creation has also been highlighted for ES (Kristensson et al., 2008; Galvagno and Dalli, 2014; Smith et al., 2014). The main focus to date, however, has been customer co-creation (Hoyer et al., 2010; Hakanen and Jaakkola, 2012; Russo-Spena and Mele, 2012). By contrast, supplier co-creation in ES was already implied in the service-dominant logic (Vargo and Lusch, 2008), and its importance has recently been highlighted 
(Pinho et al., 2014; Ayala et al., 2017; Oertzen et al., 2018). Yet, these contributions also unveil additional challenges in supplier co-creation (Oertzen et al., 2018), especially since the supplier co-creation mode may vary according to the degree of operational dependence on the supplier (Ayala et al., 2017). For example, manufacturers need to coordinate increased actor complexity and face uncertainty regarding the appropriate strategic level of supplier involvement (Lee and Schmidt, 2017). Additionally, manufacturers also must navigate the lack of understanding concerning the supplier's behavior, facing ambiguous motivations or potential opportunism (Mele et al., 2018). Thus, further investigation into the intricacies of the supplier co-creation modes in ES development and their possible effects on uncertainty is necessary.

The current literature does not offer sufficient insights into uncertainty during ES development due to two main knowledge gaps. First, limited insights exist on uncertainty and its criticality in ES development. Initial contributions in the literature have recognized the importance of uncertainty in the context of ES provision and proposed various frameworks detailing uncertainty types (Erkoyuncu et al., 2013; Kreye, 2017a). While these contributions suggest a characteristic uncertainty profile for ES provision, the uncertainty types as well as their criticality in the context of ES development remain unclear. Second, supplier co-creation has received relatively little attention within the service management literature. Studies highlight the importance of the supplier co-creation modes (Russo-Spena and Mele, 2012; Pinho et al., 2014; Saccani et al., 2014), but most have not undertaken in-depth investigations into their effect on ES development (Mendes et al., 2017; Lariviere and Kandampully, 2019). This intersection of uncertainty and its criticality in ES development and the supplier co-creation modes is the focus of this study; specifically, this study investigates the following research question:

How does supplier co-creation during engineering-service development affect uncertainty criticality of the focal organization? 
Based on the literature (Erkoyuncu et al., 2013; Durugbo and Erkoyuncu, 2016; Kreye, 2017a), this research presents a conceptual framework detailing five uncertainty types. To investigate the criticality of these uncertainty types, this research presents two in-depth case studies of extreme supplier co-creation modes: operationally independent (OI) and operationally dependent (OD) supplier co-creation. The results indicate strong differences in the criticality of specific uncertainty types according to the supplier co-creation mode, emphasizing an uncertainty reallocation. This research contributes to the service management literature by providing novel insights into uncertainty and its criticality created in two supplier co-creation modes during ES development. This advances theory of both supplier co-creation and uncertainty in ES by exploring the development of these offerings.

\section{Theoretical background}

Engineering services (ES) typically evolve when a service is added to an existing product (Kastalli and Van Looy, 2013) and are often also described as product-service systems (PSS), functional sales, integrated product-service offerings, or solutions (Gebauer et al., 2017). ES are predominant in the manufacturing industry, and engagement of them offers manufacturers the advantages of enhanced global competitiveness, stable income, and increased profits (Wise and Baumgartner, 1999; Gebauer et al., 2017).

Because ES development entails a unique set of technical, engineering, and service capabilities (Nudurupati et al., 2016) and high degrees of customization for defining the value proposition (Nordin et al., 2011), it often involves sourcing the necessary knowledge from a supplier network (Lofberg et al., 2015). This means that ES providers also need integration capabilities (Zhang et al., 2016) to enable successful co-creation within the supplier network (Pinho et al., 2014). 


\section{$2.1 \quad$ Co-creation in engineering-service development}

The precise definition of co-creation remains unsettled, especially in distinction to concepts such as integration and co-production (Galvagno and Dalli, 2014). This research builds on the common view in service management of co-creation as the "joint, collaborative, concurrent, peerlike process of producing new value" (Galvagno and Dalli, 2014). Actors within the social and technological network integrate their resources to create mutual value (Lee and Schmidt, 2017). However, supplier co-creation can also cause further challenges (Johnsen, 2009). Previous case study research has revealed that challenges can emerge regarding roles and task division, planning operations, processes of ES co-creation (Hakanen and Jaakkola, 2012), secrecy concerns, ownership of intellectual property, and information overload (Hoyer et al., 2010). It may even be a challenge to agree on a unified customer experience and the final ownership (Oertzen et al., 2018). In addition, increasing the number of participating actors increases the complexity in the development process (Pinho et al., 2014).

Modes of supplier co-creation highlighted in the literature range from the partner becoming a temporary participant and providing resources for the joint development (Russo-Spena and Mele, 2012) to the forging of a deep relationship with the partner to achieve higher degrees of quality and innovation (Johnsen, 2009; Oertzen et al., 2018). Hence, supplier co-creation can be conceptualized as a continuum depending on the degree of supplier integration (Ayala et al., 2017) see Figure 1). This continuum underlines the diversity of the possibilities for supplier engagement (Saccani et al., 2014) as well as its dynamism (Russo-Spena and Mele, 2012), as described in the literature. On one end, supplier co-creation requires supplier input regarding noncritical parts of the development process. The focal firm retains responsibility over the entire development project, and the supplier provides specific input throughout (Ayala et al., 2017). Here, the supplier input is non-central to the overall ES development (Oertzen et al., 2018) and consists of partial ideation, 
the provision of small easily replaceable work packages (software pieces, components, raw materials), or even support in the review of the design-for-manufacturability. This study defines this supplier co-creation mode as operationally independent (OI).

\section{$<$ Please insert Figure 1 about here $>$}

On the other end of the continuum is supplier co-creation that involves close collaboration with the supplier where the success of ES development highly depends on the supplier's capabilities and close collaboration in the process (Ayala et al., 2017). The supplier is more broadly engaged in various stages of the development and assumes responsibilities for central tasks in ES development (Oertzen et al., 2018). This may include tasks with end-to-end responsibility for a whole subsystem of the product or service or complete software systems, with a need for subsequent integration into the overall ES. The supplier and the focal organization share responsibility over the entire development process (Lee and Schmidt, 2017). This study defines this supplier co-creation mode as operationally dependent (OD).

\subsection{Uncertainty in engineering-service development}

This paper draws upon the definition of uncertainty as a lack of understanding (Kreye et al., 2012). More specifically, this study adopts the following definition of uncertainty: "A potential deficiency in any phase or activity of the process, which can be characterized as not definite, not known or not reliable" (Kreye et al., 2012). Thus, understanding refers to a decision maker's interpretation of a situation, including their confidence in predicting an event (Erkoyuncu et al., 2014). This definition enables to include two fundamental views on uncertainty: the view of uncertainty as unpredictability (Kreye, 2017a) and the view of uncertainty as variability (Frei, 2006; Durugbo and Erkoyuncu, 2016). Uncertainty means that managers and members of the development team may not have the necessary understanding they need to make their decisions (Kreye, 2017a). 
Uncertainty criticality refers to the potential impact of uncertainty on a project, and specifically, this refers to the relative magnitude of an uncertain event in the context of the considered project. This can imply, for example, a temporal impact, such as a delay or increased urgency (Chen et al., 2005; O'Connor and Rice, 2013), a financial impact, such as increased costs or a reduced budget (Erkoyuncu et al., 2014), or a qualitative impact, such as customer satisfaction or failure rates (Sicotte and Bourgault, 2008; Cheng and Krumwiede, 2017).

Uncertainty and its management are highly central for ES development to create a successful offering (Sakao et al., 2009). Conceptual connections of uncertainty can be drawn from the literature on service management (Erkoyuncu et al., 2011; Cheng and Krumwiede, 2017; Kreye, 2017a) and the adjacent literature of NPD (Sicotte and Bourgault, 2008; O'Connor and Rice, 2013; Melander and Tell, 2014). Table 1 presents exemplary definitions of the uncertainty types.

\section{$<$ Please insert Table 1 about here $>$}

Across these two literature streams, this study identified uncertainty types with strong overlaps in their definitions. For example, organizational uncertainty caused by organizational dynamism has been highlighted in the context of NPD (Melander and Tell, 2014), as well as service management (Erkoyuncu et al., 2013). By contrast, some uncertainty types have been described in only one of the two literature streams (service management or NPD). For example, only the NPD literature has described technical uncertainty as a lack of experience with novel technologies (Tatikonda and Rosenthal, 2000). Similarly, only the service management literature has defined relational uncertainty as the unpredictability of a partner's actions (Kreye, 2017b).

This study synthesizes these literature streams to study five uncertainty types in supplier cocreation for ES development. All these uncertainty types generally entail both uncertainty views, namely unpredictability and variability, with typically one dominant view. The five uncertainty types seem to have the most acceptance across both fields of service management and NPD and 
also account for the specific nature of ES. The five types, namely environmental, technical, organizational, resource, and relational uncertainty, are described in turn.

Environmental uncertainty is discussed in both the service management and NPD literature and is defined as the unpredictability of the external environment (Cheng and Krumwiede, 2017). This generally accepted definition relates directly to the uncertainty view of unpredictability (Kreye, 2017a). However, some conceptualizations of environmental uncertainty in a service context, including supply and demand uncertainty (Erkoyuncu et al., 2011), position variability as the central element of uncertainty (Frei, 2006; Durugbo and Erkoyuncu, 2016). Thus, for the conceptualization of environmental uncertainty, this study integrated both aspects aligned with the overarching definition of uncertainty, and relates specifically to its source in the external environment (Kreye, 2017b). Environmental uncertainty differs from market uncertainty, which is predominantly the focus of the NPD literature (Chen et al., 2005; Sicotte and Bourgault, 2008; O'Connor and Rice, 2013) and is defined as the degree to which customer needs are well understood and converted into a market application (O'Connor and Rice, 2013). Environmental uncertainty, by contrast, includes the wider business context of competitors, suppliers, and larger macro-developments in the industry (Sicotte and Bourgault, 2008). It thus includes the provider's responsibility for the product's long life cycles (Kindström and Kowalkowski, 2009) and has been predominantly used in the context of ES (Cheng and Krumwiede, 2017). Moreover, the shift towards ES has a disruptive effect on the market and changes the competitive landscape (Gebauer et al., 2017).

Technical uncertainty is well established in the NPD literature and is defined as the degree to which the scientific knowledge needed for the development of the offering is well understood (Tatikonda and Rosenthal, 2000). It arises due to the technical novelty of the newly developed offering and the resulting lack of understanding (Chen et al., 2005; Sicotte and Bourgault, 2008; 
O'Connor and Rice, 2013). For ES, technical uncertainty may relate to the product part of the offering and can refer to the degree of scientific knowledge and its conversion into a cost-efficient, reliable, and manufacturable technology platform (O’Connor and Rice, 2013). Technical uncertainty may also arise from the service part of the offering in terms of the high degree of complexity due to customization (Nordin et al., 2011). Similarly, the systematic integration of product and service due to the complexity of interface management (Gebauer et al., 2017) may further increase technical uncertainty.

Organizational uncertainty has been described separately for service management (Cheng and Krumwiede, 2017; Kreye, 2017b, 2017a) and NPD (Sicotte and Bourgault, 2008; O'Connor and Rice, 2013; Melander and Tell, 2014). It is defined as the variability of an internal organization due to organizational dynamism and includes both the development team as well as the wider organization (O’Connor and Rice, 2013). This uncertainty type generally resembles the uncertainty conceptualization of variability (Frei, 2006; Sicotte and Bourgault, 2008; O'Connor and Rice, 2013) but has also been conceptualized as the unpredictability of the strategic and operational flexibility of an organization (Melander and Tell, 2014; Kreye, 2017b). Organizational uncertainty in ES can relate to changes in the strategic importance of a service offering with respect to the organization's goals ( $\mathrm{Ng}$ et al., 2012). It may also arise from increased complexity in navigating the difference in the business logic between product- and service-centered businesses (Grönroos and Helle, 2010). In addition, the need to increase understanding of novel roles, functions, and processes required for a new offering (Kastalli and Van Looy, 2013) can also create organizational uncertainty.

Resource uncertainty is discussed in both service management (Lievens and Moenaert, 2000) and NPD (O'Connor and Rice, 2013) literature and is defined as the unknown availability of appropriate financial, technical, and human resources (Lievens and Moenaert, 2000) used during 
development. Resource uncertainty includes the ability to attract and retain resources (O'Connor and Rice, 2013), including financial resources, expertise, critical information, hardware, or software (Lievens and Moenaert, 2000). It has mostly been discussed as variability in resource availability (Frei, 2006; Erkoyuncu et al., 2011; Melander and Tell, 2014) but has also been discussed as unpredictability in resource attraction (O'Connor and Rice, 2013). Here, the manufacturer's ability to source capabilities and resources it lacks for ES development through engaging in supplier co-creation (Lee and Schmidt, 2017) may suggest an impact of co-creation on resource uncertainty.

Relational uncertainty has been investigated in the service management literature and is defined as the unpredictability of a collaborator's actions due to lack of understanding of the partner's attitudes, feelings, and behavior (Kreye, 2017b). It relates exclusively to the unpredictability conceptualization of uncertainty (Kreye, 2017a) and can manifest itself through conflicts caused by ambiguity, opportunism, or conformity issues (Russo-Spena and Mele, 2012). Relational uncertainty depends on the level of interaction between the partners (Kreye, 2017a) and may thus differ for different supplier co-creation modes.

\subsection{Conceptual framework}

To investigate the research question, this study defines a conceptual framework of five uncertainty types and their potential operationalization in the context of ES development (see Table 2). These five uncertainty types are subsequently analyzed with particular focus on their criticality in the differing supplier co-creation modes, namely OD and OI, in ES development.

\section{$<$ Please insert Table 2 about here $>$}

\section{Method}

To investigate the research question, this research adopted an exploratory design via a case study approach for the following reasons. Due to the lack of mature insights in the field, no testable 
hypotheses could be formulated (Eisenhardt, 1989). Case study research, however, enables exploratory research through in-depth investigation of a phenomenon in its original environment. It generates empirical evidence for the creation of an initial understanding of the phenomenon and theory building (Yin, 2009). Furthermore, the organizational setting and the industrial environment may determine the research observations for engineering services (ESs) (Kastalli and Van Looy, 2013). The case study approach enables studying the context-specific setting of ES development. In line with high-quality case study research in service management (Kreye, 2017a; Verleye, 2019), this study followed Yin's (2009) structured case study approach and initially outlined it in a case study protocol.

\subsection{Case selection}

This study presents evidence from two case studies (Yin, 2009) focusing on ES development. Investigation of these extreme cases of the supplier co-creation continuum enables a deeper understanding of the phenomenon under analysis (Eisenhardt and Graebner, 2007). Through application of theoretical sampling, the study chose the extreme cases strategically based on theoretical criteria to observe the contrasting patterns from the extreme ends of the supplier cocreation continuum. This comparison provides deep insights into uncertainty criticality in original contexts. The cases differed in their supplier co-creation mode. Following the rationale of extreme case selection (Flyvbjerg, 2006), the study chose two cases from either end of the supplier cocreation continuum. Case 1 focused on OI supplier co-creation (left side of continuum in Figure 1). The suppliers became temporary participants, while the focal company maintained full responsibility over the development project and thus operated with relative independence from the suppliers. Case 2 focused on OD supplier co-creation (right side of continuum in Figure 1). The suppliers developed critical hardware and software subsystems for the overall ES, making the focal organization highly operationally dependent. The cases were bounded regarding the respective 
focal organizations that operated as integrators, and the suppliers engaged in the co-creation process. To protect the identities of the companies, the detailed case context and company names were anonymized. Moreover, the cases differed with regard to the industry sector. Case 1 was set in the mining industry, and Case 2 was set in the food equipment industry.

Both cases focused on the development of a similar type of ES, namely consultancy for machine performance optimization based on condition monitoring, as well as a full-scope maintenance and spare parts supply contract. In addition, the cases were of similar complexity, resource involvement, and length, and both companies were large manufacturers with international operations. Both case organizations were multinationals with headquarters in Europe that provide a holistic portfolio of ESs, ranging from maintenance and supporting services to the operation of processing facilities. These similarities enabled robust comparability of the two cases. The similarities and differences between the two cases enabled triangulation of the findings to ensure that the findings are not idiosyncratic to the single case or its environmental embedding (Eisenhardt and Graebner, 2007).

\subsection{Data collection}

Data from multiple sources of information were collected retrospectively towards the end of the development projects (Eisenhardt and Graebner, 2007). The predominant data source was semistructured expert interviews. In total, 18 semi-structured interviews across both cases (10 for Case 1 and 8 for Case 2) were conducted, including follow-up interviews, which were conducted to obtain clarifications and further insights into specific case-related areas. The interviewees were selected based on their involvement in the ES development and experience with the suppliers, and they included mainly members of the core development team. For additional insights and triangulation, one representative from supplier 2 from Case 2 was also interviewed. Other suppliers were not interviewed because the focus of the study was on the focal organization. A semi- 
structured interview questionnaire (see Appendix) based on the conceptual framework to investigate different uncertainty types guided the interviews. To avoid bias (Kreye, 2017a), the interviews did not specifically discuss "uncertainty." Rather, the questionnaire focused on identifying the sources of uncertainty through an indirect approach of asking the interviewees to discuss the challenges encountered in the course of ES development and investigating their criticality through asking about their impact. The interviews lasted between 25 minutes and 1.5 hours with a mean of 1 hour and were conducted one-on-one in person or via videoconference. All interviews were recorded and subsequently transcribed for data analysis.

In addition, the study collected supporting project documentation, which included meeting minutes, status reports, gate/steering committee presentations, and the overview of the development process. The inventory of secondary data comprised 30 supporting project documents across both cases (21 for Case 1 and 9 for Case 2 ). During and after the interviews, field notes were prepared, which aided in identifying the themes that needed further investigation. Table 3 summarizes the collected data of the two cases.

\section{$<$ Please insert Table 3 about here $>$}

The collection and analysis of additional data and interviews were conducted until theoretical saturation was reached (Eisenhardt, 1989). To maintain consistency, the same researcher collected data for both cases between January and February 2018. The researcher conducted the interviews in English, German, and Spanish, being fluent in all three languages. This enabled data collection and analysis to be performed in the original language. The specific most representative quotes were translated for inclusion in this article while keeping as close as possible to the original meaning, as recommended by Strauss and Corbin (1998). 


\subsection{Data analysis}

Data were carefully analyzed using an abductive approach in two main steps. First, a withincase analysis of the uncertainty types occurring in each individual case was conducted. Initially, the main author coded the emerging themes inductively based on the data and the case-specific insights. The researcher used first-order codes to summarize the emerging concepts and cluster them into higher-level uncertainty instances. In this step, the researcher applied data triangulation and validated the findings of interviews among further interviews as well as with the supporting project documentation. The aim was to create a rich and holistic picture of the uncertainty instances and their criticality. Second, the author team jointly coded the data deductively based on the conceptual framework by utilizing primary codes. Through the course of several iterations, the author team refined the coding structure by identifying links between the deductive codes and the local, inductively emerging instances in the case study. To achieve this, the researchers travelled back and forth between the empirical data and the literature, achieving increasing levels of abstraction. Moreover, they continuously refined the coding structure as they developed a more precise definition and shared understanding of the uncertainty types (Miles et al., 2014). In addition, co-creation-specific uncertainty instances were identified in the within-case analysis based on the definition of Galvagno and Dalli (2014).

The main author, who conducted the interviews, also analyzed the criticality of the uncertainty instances based on their relative impact on the project using a 3-point scale (high, moderate, low). Due to the retrospective nature of the collected data, uncertainty criticality was determined according to the actual impact of the uncertainty instances on the overall development project (e.g., strong time delay or high financial loss). Specifically, the criticality assessment entailed two central steps. First, the main author assessed each uncertainty instance based on its individual criticality. This assessment emerged from the expert assessment of the interviewees who reflected on the 
relative impact of each uncertainty instance on the overall project. Second, the overall criticality of the uncertainty type emerged as the aggregate impact of the uncertainty instances. This resulted in in-depth coding of the criticality of each uncertainty type, including the specific instances.

Second, both authors jointly performed a cross-case analysis by comparing and contrasting the identified categories (Yin, 2009). Through an iterative process, an increasingly higher level of abstraction in the identified common and differing categories within each uncertainty type was achieved (Miles et al., 2014), and these categories were clustered into second-order codes. The results of the iterative approach provided the empirical evidence with regards to the research focus. The cross-case analysis enabled comparison of the criticality of the different uncertainty types in the ES development between the two extreme supplier co-creation modes. Table 4 depicts an excerpt of the codes from the data analysis.

\section{$<$ Please insert Table 4 about here $>$}

According to the guidelines for high-quality case study research in service management (Kreye, 2017a; Verleye, 2019), this study followed Yin's (2009) structured case study approach, paying close attention to ensuring construct validity, internal validity, external validity, and reliability. To ensure the construct validity and case study rigor, the analysis was based on multiple sources of data, and the findings were triangulated among each other to establish a chain of evidence (Miles et al., 2014). Further, key informants from the involved organizations reviewed and commented on both a draft of the case study report as well as the conclusions derived from the data analysis (Verleye, 2019). To promote high internal validity, the research framework was derived explicitly from the literature, and the patterns identified in the literature matched with the findings in the case study (Gibbert et al., 2008). External validity was achieved through the use of theory derived from uncertainty in the service management and NPD literature as well as the focus on analytical generalization based on an extreme case study. Here, close attention was paid to the 
case selection criteria with respect to their comparability and difference in the critical phenomenon under analysis (Yin, 2009). Reliability was assured through the creation of a case study database of all available documents, including interview transcripts, archival data, and the field notes and observations (Gibbert et al., 2008). Moreover, the structured case study approach was initially outlined in a case study protocol (Yin, 2009), and the data analysis procedure is explained in detail (Gibbert et al.,2008).

\section{$4 \quad$ Findings}

\subsection{Case 1-Operationally independent supplier co-creation in the mining industry}

Case 1 focused on ES development regarding condition monitoring of the case company's grinding equipment, including 3D scans to predict the wear trend and optimize the wear parts accordingly. Two suppliers provided noncritical resources such as a version of a software for the analysis and continued engaging in the development project through consultancy and software support. This resulted in relative independence of the focal company from its chosen suppliers. According to the Monthly Meeting Minutes, "After tests (...) the choice fell on [software from supplier 2] (...) The accuracy is higher when using [software from supplier 2, as opposed to another $3^{\text {rd }}$ party] (...) What counts in favor of [external software 2] is that the [case company subsidiary] has obtained excellent experience using this software." This shows that the case company intended to use the software of supplier 2 in the development project without close integration and operational dependence on the supplier due to available in-house expertise in the use of the software. The involvement of the supplier entailed only the provision of the software as well as partial guidance in the use of the software. Thus, the case company retained full responsibility over the entire development project, especially since it already had partial experience in the use of the software. 
The ES development project represented a reaction to highly critical environmental uncertainty caused by strong competition. This environmental uncertainty created an urgent need to shift towards ES provision and develop a competitive offering. This in turn created moderately critical technical uncertainty about the precise scoping of the offering as well as highly critical organizational uncertainty with respect to the definition of novel functions and processes for the service execution, including the definition of tasks and responsibilities, establishment of internal procedures, and service coordination on a global scale. In addition, organizational uncertainty disrupted the project in the form of a department reorganization, which split the research and development (R\&D) department into two R\&D subgroups, causing uncertainty attributable to rotating employees and the definition of new roles. The project manager explained the impact: "Our R\&D will be split into [part 1] and [part 2], and [development engineer 1] will go to [part 1], which means that he will have to leave our project because we are in [part 2] with the [ES development project]... There have also been several issues with [development engineer 1] leaving... because [the new development engineer] still has to learn. So that also takes some time." The reorganization caused resource uncertainty of high criticality regarding the availability of staff for the ES provision as well as the availability of specialized skills for ES development. The engagement in OI co-creation with a supplier who provided the necessary software and consultancy partially relieved that uncertainty. The project manager described it as follows: "We tried to use the low-cost solution [internal software 1] and [internal software 2], but with the many data points it got very slow (...) So then, we eventually purchased a license for [software 3 from the supplier 1]." The collaboration experience with both suppliers was overall positive, as the project manager described: "Our suppliers have helped us a lot. For example, we showed [supplier 1] our data and they actually helped us to develop the post-processing [of the data] (...) And [supplier 1 and 2] always came to our office when we needed them." However, the engagement of supplier 1 caused 
resource uncertainty of low criticality regarding the quality of the supplier's deliverable (faulty software updates). The project manager described this as follows: "The results were wrong, and we thought we did something wrong (...) So we really tried to understand the mistake internally before going to [supplier 1]." Finally, no relevant instances of relational uncertainty were observed. Table 5 summarizes the uncertainty types in the case.

<Please insert Table 5 about here $>$

\subsection{Case 2-Operationally dependent supplier co-creation in the food equipment} industry

Case 2 described a condition monitoring tool used to monitor and analyze the machine parameters of separators and homogenizers to optimize the machine performance and the surrounding production process. The five suppliers provided central hardware or software subsystems for the overall ES. Based on a long common history, the focal organization decided to further deepen this relationship with the suppliers through the joint execution of the development project. Service product manager 1 described a representative example of the supplier relationships, specifically the critical dependence on supplier 2: "It was a strategic decision because we already did a lot with [supplier 2]. But then you put your trust in [supplier 2] because then you have everything from a single source (...) The problem was the entire software package from [supplier 2] because since that didn't work, the hardware could have been perfect, it just wouldn't have worked. And that was actually the biggest problem because [supplier 2] had to learn a lot." This indicates that it was a strategic decision of the focal company to engage in a deep relationship with supplier 2. Since this supplier provided a highly critical component, software central to the ES, the relationship was highly operationally dependent. The information technology (IT) product manager described the general scope of involvement of all suppliers: "So there was [supplier 1, supplier 2, supplier 3, supplier 4, and supplier 5]. They were all large companies. And to coordinate all of 
them for the whole project, we then agreed on [having] regular steering meetings (...) because it is important that you coordinate what the status is and what needs to be done. And especially from [supplier 1 and 2], there always had to be someone there." This shows that all suppliers in Case 2 were closely engaged in the project throughout various stages of the development.

Environmental uncertainty through increased competition was of high criticality and motivated project initiation. In addition, regulatory changes in the European market, the General Data Protection Regulation (GDPR), impacted the customer's behavior by necessitating increased data protection standards, and this challenged the case company's ability to offer the ES. The environmental uncertainty impacted the technical uncertainty of high criticality through struggles relating to the commercial scoping and the accuracy of modeling and forecasting their machine performance. An IT $2^{\text {nd }}$ level support employee explained, "Our main problem was the interfaces (...) because the interfaces between [software from supplier 2] and the remaining [ES] system did not work." Technical uncertainty caused a time delay of the project of 1.5 years.

Organizational uncertainty arose around the organizational resistance to the establishment of a service culture within case company 2. Employees were unsupportive of the new, more advanced type of ES; according to the IT product manager, "In the beginning, most people refused until they realized that it makes sense. Especially in order processing or the service technicians. There was really not much motivation to work in there." Resulting from the uncertainty around organizational support, problems in the process of resource provision arose, causing resource uncertainty of moderate criticality. The development team struggled with attracting the required resources needed for training and executing $2^{\text {nd }}$ level support staff for the ES. Yet, the OD engagement of suppliers in the ES development provided case company 2 access to knowledge that was not present in-house and partially compensated for the lack of staff. Moreover, resource uncertainty arose from the quality of the technical deliverable of the supplier. For example, supplier 1 provided faulty 
hardware, as explained by the project manager: "The [hardware] of [supplier 1] did not meet our quality standards during the tests... it took us a long time to find out that the [hardware] was the root cause." This in turn gave rise to relational uncertainty. Specifically, supplier 2 had a hidden agenda of developing a standardized version of the software package instead of the previously bespoke customized offering they agreed upon with case company 2 . The technical project manager (from supplier 2) explained, "Of course we have an interest in offering this software as a standard software." The IT product manager explained the viewpoint of case company 2: "And even though we really had talked in great detail about everything beforehand... still we have a long list of requirements... which [supplier 2] still has not implemented properly." This created many difficulties for the ES development, threatening the viability of the offering. Table 6 summarizes the uncertainty types of the case.

\section{$<$ Please insert Table 6 about here $>$}

\subsection{Cross-case analysis}

The cross-case analysis identified similarities in the criticality of the five uncertainty types. In both cases, environmental uncertainty was highly critical and arose from an increase in competition and the determination of the actual value for the customer of the ES. Similarly, organizational uncertainty was highly critical for both cases but exhibited similarities (e.g., definition of functions and processes) and differences (Case 1, e.g., a cost conscious culture; Case 2, e.g., a lack of a service culture). Neither uncertainty type showed supplier co-creation-related instances. This suggests that environmental and organizational uncertainty are central for ES development in general and independent of the supplier co-creation mode.

Differences between the cases concerned technical, relational, and resource uncertainty. Technical uncertainty was observed to be more critical in Case 2 (OD supplier co-creation). Here, additional instances arose from the interfaces of the supplier's software deliverable, suggesting a 
connection between the degree of technical uncertainty experienced during ES development and the supplier co-creation mode.

Relational uncertainty exhibited a similar difference. Whereas Case 1 (OI supplier co-creation) showed no explicit evidence of relational uncertainty, Case 2 (OD supplier co-creation) had highly critical relational uncertainty caused exclusively by the supplier co-creation mode. This suggests that the degree of relational uncertainty experienced during ES development is dependent on the supplier co-creation mode.

Finally, resource uncertainty exhibited a contrasting uncertainty profile as Case 1 (OI supplier co-creation) showed evidence of high uncertainty criticality and Case 2 (OD supplier co-creation) was only of moderate uncertainty criticality. Although both cases struggled with some similar instances, the critical difference emerged from technical resources provided by the suppliers (i.e. tool suitability). While Case 2 sourced these technical resources from the supplier, Case 1 struggled with the internal technical resources before deciding to source them through supplier engagement. Thus, resource availability for ES development through deeper supplier engagement in Case 2 enabled them to reduce their resource uncertainty, whereas Case 1 needed to initially manage resources themselves, incurring higher resource uncertainty.

\section{Discussion}

\subsection{Key research insights}

The findings showed two key research insights regarding the uncertainty profile of different supplier co-creation modes in engineering-service (ES) development. First, the findings suggest that organizational and environmental uncertainty are of high criticality for ES development, independent of the supplier co-creation mode. Second, due to differences found in the two cases, the findings suggest that the criticality of technical, relational, and resource uncertainty depend on 
the supplier co-creation mode. However, the uncertainty profile for this dependence differs for the specific uncertainty types.

The first key insight indicates that environmental and organizational uncertainty are of high criticality for ES development, suggesting independence from the supplier co-creation mode. Although the specific uncertainty instances varied across the cases, they generally reflected existing examples discussed in the service management literature. For environmental uncertainty, these included uncertainty instances involving the customer (Kristensson et al., 2008; Smith et al., 2014) as well as broader instances related to the competitive setting (Fischer et al., 2010; Gebauer et al., 2017) and vulnerability towards larger macro-economic or legal developments (Kindström and Kowalkowski, 2009; Kreye, 2017a). For organizational uncertainty, these instances included organizational change (O'Connor and Rice, 2013), the definition of novel functions and processes (Nudurupati et al., 2016), and the establishment of a service culture ( $\mathrm{Ng}$ et al., 2012). The cases evidenced high criticality of environmental and organizational uncertainty, mostly through strong temporal project impacts, such as a major time delay, increased urgency (Chen et al., 2005; O'Connor and Rice, 2013), and a threat to delay the time to market substantially, which would decrease the competitive advantage. The findings suggest that environmental and organizational uncertainty are of high criticality for ES development in general, independently of the supplier cocreation mode.

The second key insight indicates strong differences in the criticality of technical, relational, and resource uncertainty between the contrasted supplier co-creation modes. For technical uncertainty, the findings suggest moderate criticality in OI supplier co-creation and high criticality in OD supplier co-creation. Technical uncertainty in OI supplier co-creation was focused on the precise scoping of the offering or the modeling and forecasting of the ES, which accords with the literature in the field (Chen et al., 2005; Nordin et al., 2011). Such uncertainty represented a severe, 
but not existential, impediment to the success of the ES on the market, reflecting moderate criticality. Technical uncertainty in OD supplier co-creation related to managing the interfaces between the supplier's deliverables and the overall ES, which also accords with the literature (Nordin et al., 2011; Gebauer et al., 2017). Due to strong operational dependence, the nonresolution of these technical challenges posed an existential threat to project success and was thus highly critical. This increase in technical uncertainty is reflected in the literature which has highlighted challenges of integration centered on the integration of the partner's deliverable and indicates the direction of the causality, where deep supplier integration leads to more technical uncertainty due to more instances of critical uncertainty. However, the NPD literature suggests that the opposite might also be true, where high technical uncertainty motivates engagement in OD supplier cocreation (Primo and Amundson, 2002). While the direction of causality is yet to be determined, the distinction of the supplier co-creation mode of the present study offers a deeper and more nuanced view to discussions on the causality between supplier co-creation and technical uncertainty (Johnsen, 2009). The findings thus suggest dependence between the criticality of technical uncertainty and the supplier co-creation mode, with higher criticality for OD supplier co-creation.

Similarly, the findings concerning relational uncertainty suggest a strong difference between the supplier co-creation modes. The OI supplier co-creation mode exhibited no instances of relational uncertainty, reflecting low criticality. Yet, the literature describes the relevance of relational uncertainty for ESs when external partners are involved (Kreye, 2017b), suggesting the potential of this uncertainty type also exists for OI supplier co-creation. By contrast, the OD supplier co-creation mode exhibited highly critical instances of relational uncertainty arising from the supplier's knowledge and ability, hidden agendas of the supplier, as well as misunderstandings due to differing native or vernacular languages. These instances threatened overall project continuity, making relational uncertainty highly critical. This is also evident in the literature that 
addresses challenges in supplier co-creation resulting from ambiguity, opportunistic behavior, and conflict management (Mele et al., 2018). The findings thus suggest dependence between the criticality of relational uncertainty and the supplier co-creation mode.

In contrast, the findings for resource uncertainty suggest the reversed uncertainty profile in the supplier co-creation modes. Whereas Case 1 (OI supplier co-creation) lacked highly critical software tools and expertise, existentially threatening the ability to develop the ES, Case 2 (OD supplier co-creation) was able to source these externally, thus reducing the criticality of resource uncertainty. This was particularly prevalent in the provision of technical resources (software; Lievens and Moenaert, 2000) or specialized skills (Kreye, 2016) by the supplier. For Case 2, the supplier provided necessary central resources, and the immediate resolution of the remaining resource challenges was not urgent, making resource uncertainty less critical. These findings suggest a dependence between the criticality of the resource uncertainty and the supplier cocreation mode, with lower criticality for OD supplier co-creation.

\subsection{Proposed framework of uncertainty in supplier co-creation in engineering-service}

\section{development}

Based on these two key research insights, this study proposes a conceptual framework detailing the uncertainty profiles of the two extreme supplier co-creation modes (OI and OD) in ES development (Figure 2). This research highlights the centrality of the uncertainty concept for ES development, since the majority of the uncertainty types were of moderate and high criticality. This accords with the emphasis on the uncertainty concept in the wider service management literature (Erkoyuncu et al., 2014; Cheng and Krumwiede, 2017; Kreye, 2017a). The framework shows the changing uncertainty profiles on either end of the supplier co-creation continuum across the five investigated uncertainty types. While the criticality of organizational and environmental uncertainty remained similar across the two extremes of the conceptual framework, dependencies 
appear to have been associated with technical, relational, and resource uncertainty. Specifically, the criticality of technical and relational uncertainty was high when entering into an operationally dependent relationship with a supplier, while the criticality of resource uncertainty was reduced. This has a strong impact on uncertainty management during ES development, as the supplier cocreation mode entails an uncertainty reallocation among the uncertainty types.

\section{$<$ Please insert Figure 2 about here $>$}

The differential effect of uncertainty on various co-creation modes has not been highlighted before and thus the future study of similar effects in adjacent domains such as new service development (NSD) or NPD is warranted. For example, the high importance of relationships and the strong need for customization of ES is also highly relevant for other professional services (Lewis and Brown, 2012), which could imply similar centrality of relational and technical uncertainty for NSD. In addition, engagement in co-creation as observed for ES development has also been highlighted for NPD (Primo and Amundson, 2002; Hoyer et al., 2010; Melander and Tell, 2014), suggesting that relational uncertainty might be relevant in this context. The differential view on uncertainty potentially relieves some of the ongoing disagreement on the relationship between uncertainty and co-creation (Johnsen, 2009).

\section{Conclusion}

This study investigated the following research question: How does supplier co-creation during engineering-service development affect uncertainty criticality of the focal organization? On the basis of the comparison of two case studies, which differed in their supplier co-creation mode, operationally independent (OI) and operationally dependent (OD), this paper investigated the criticality of five uncertainty types (environmental, technical, organizational, resource, and relational uncertainty) faced during ES development. The findings go beyond the macro 
exploration of uncertainty and offer instead a nuanced view of the uncertainty criticality of two extreme supplier co-creation modes in ES development.

This research contributes to the service management literature in two respects. First, the research expands theory on supplier co-creation in ES development (Vargo and Lusch, 2008; Pinho et al., 2014; Ayala et al., 2017) through the proposed framework of the varying uncertainty profiles experienced by the focal organization in two extreme supplier co-creation modes (OI and OD). This reveals the impact of the supplier co-creation mode through an uncertainty reallocation among technical, relational, and resource uncertainty. By contrast, environmental and organizational uncertainty appear to have high relevance for ES development in general, independently of the supplier co-creation mode. This study thus offers a nuanced view of the concept of supplier cocreation through the distinction of various supplier co-creation modes through the lens of uncertainty. This contributes to discussions of value co-creation in ES development (Russo-Spena and Mele, 2012; Oertzen et al., 2018; Lariviere and Kandampully, 2019) and expands these insights through the proposed framework of uncertainty.

Second, this research contributes to theory expansion on uncertainty in ES (Erkoyuncu et al., 2013; Erkoyuncu et al., 2014; Kreye, 2017a) through its exploration of ES development. In this manner, this study complements existing insights, which have predominantly focused on ES provision (Erkoyuncu et al., 2013; Cheng and Krumwiede, 2017; Kreye, 2017b). This study provides an overarching explanation of the challenges encountered by manufacturers in ES development through incorporating the uncertainty perspective. This deeper understanding of ES development through uncertainty is of substantial value for both theory and practice due to the front-loaded nature of ES, specifically because the development creates the crucial foundation for subsequent performance during operations (Kindström and Kowalkowski, 2009). This study thus extends current theory on ESs by providing the basis for furthering understanding of uncertainty 
in ES development specifically, and more generally, including the development of these offerings into the ongoing operations debate.

\subsection{Managerial implications}

This research provides central implications for practice. The developed framework provides practitioners with a valuable guideline for better managing uncertainty during ES development through the presentation of an uncertainty typology as well as examples of its operationalization in the two extreme modes of supplier co-creation. This study suggests paying close managerial attention to environmental and organizational uncertainty in general and using the specific supplier co-creation mode as a strategic tool to affect the uncertainty profile of the development project. Although high operational dependence seems to promise less resource uncertainty, it also appears to imply higher technical and relational uncertainty. Thus, the study creates awareness that supplier co-creation seems to represent an uncertainty reallocation and helps managers to evaluate the trade-off regarding which uncertainty types to face during their specific ES development project. Concrete steps for applying the framework could be as follows: First, practitioners can assess the trade-off between resource uncertainty against technical and relational uncertainty when considering supplier integration. Guiding criteria can be the capability of the focal organization to manage the respective uncertainty types. Second, based on the degree of supplier integration, practitioners can equip the project team accordingly. This may imply additional training of team members in technical ES-related skills for OI supplier co-creation or the consideration of adding time buffers around the supplier deliverables to allow for possible fault-tracing in OD supplier cocreation. Third, practitioners can manage uncertainty throughout the development project based on the five uncertainty types, using the case incidents as examples of possible challenges. 


\subsection{Limitations and future research}

This research is subject to several limitations. First, qualitative research, especially case study research, has been connected to observer bias towards verification and the consequent tendency for researchers to confirm preconceived notions (Flyvbjerg, 2006). This limitation was mitigated through the application of intra-data and inter-data triangulation to improve reliability (Miles et al., 2014).

Second, qualitative results are often challenged by the claim of low generalizability (Flyvbjerg, 2006). This limitation was addressed in the study design through a strategic selection of cases, where extreme cases often reveal more information (Yin, 2009) and enable a clear recognition of the central constructs of a phenomenon (Eisenhardt and Graebner, 2007). As such, the cases in the present research had a high degree of similarity (offering, company type, industry), whereas they differed extremely in the phenomenon of analysis, namely the supplier co-creation mode. Moreover, the present findings are based on the analysis of two "polar cases" of the dependence continuum, yielding highly illuminating information about the phenomenon (Flyvbjerg, 2006). Finally, the purpose of the research was to develop theory rather than test it. Thus, the approach of theoretical sampling was appropriate (Eisenhardt and Graebner, 2007).

Third, although the findings may be analytically generalized to the context of ES development, it is central to understand the boundary conditions within which they apply (Yin, 2009). For the present case study, this refers to the development of an ES in the manufacturing industry. Moreover, the implications represent either end of the extreme supplier co-creation modes (OI or OD). As such, this study distances itself from pure hardware or service development, moderate (not extreme) OI/OD co-creation, as well as mixed OI/OD relationships with multiple suppliers and points towards an understanding of these findings in their specific industrial, cultural, and temporal setting. 
Further research is needed to expand on the insights provided in this paper. First, confirmatory research is required to test the derived framework for refinement and theoretical development. Specifically, this would target the uncertainty criticality, as only one of the uncertainty types was assessed as "low." Exploratory research could investigate the deeper reason behind this, as it could be case-specific or due to the radical nature of the ES offering for traditional manufacturers. Second, further work needs to be done on co-creation with suppliers. For example, the analysis of a potential impact of partner diversity on uncertainty (e.g., mixed OI/OD relationships). Third, further empirical research could document the dynamic interrelations between uncertainty types. This research suggests a domino effect (e.g., environmental uncertainty creating technical uncertainty in ES co-creation); however, further in-depth evidence is needed in this regard. Fourth, further research needs to establish a project management framework for the uncertainty types. The differentiation into five uncertainty types suggests that different project management approaches are required in response to them; however, more conclusive evidence is needed. 


\section{References}

Ayala, N. F. et al. (2017) 'Knowledge sharing dynamics in service suppliers' involvement for servitization of manufacturing companies', International Journal of Production Economics, 193(August 2016), pp. 538-553. doi: 10.1016/j.ijpe.2017.08.019.

Chen, J., Reilly, R. R. and Lynn, G. S. (2005) 'The impacts of speed-to-market on new product success: The moderating effects of uncertainty', IEEE Transactions on Engineering Management, 52(2), pp. 199-212. doi: 10.1109/TEM.2005.844926.

Cheng, C. C. J. and Krumwiede, D. (2017) 'What makes a manufacturing firm effective for service innovation? The role of intangible capital under strategic and environmental conditions', International Journal of Production Economics. Elsevier Ltd, 193(March 2016), pp. 113-122. doi: 10.1016/j.ijpe.2017.07.007.

Durugbo, C. and Erkoyuncu, J. A. (2016) 'Mitigating uncertainty for industrial service operations: a multi case study', International Journal of Operations \& Production Management, 36(5), pp. 532-571. doi: 10.1108/IJOPM-04-2015-0196.

Eisenhardt, K. M. (1989) 'Building Theories from Case Study Research', The Academy of Management Review, 14(4), p. 532. doi: 10.2307/258557.

Eisenhardt, K. M. and Graebner, M. E. (2007) 'Theory Building From Cases: Opportunities and Challenges', The Academy of Management Journal, 50(1), pp. 25-32. Available at: http://amj.aom.org/content/50/1/25.short.

Erkoyuncu, J. A. et al. (2011) 'Understanding service uncertainties in industrial productservice system cost estimation', International Journal of Advanced Manufacturing Technology, 52(9-12), pp. 1223-1238. doi: 10.1007/s00170-010-2767-3.

Erkoyuncu, J. A. et al. (2014) 'An innovative uncertainty management framework to support contracting for product-service availability', Journal of Service Management, 25(5), pp. 603-638. 
doi: 10.1108/JOSM-07-2013-0193.

Erkoyuncu, J. A., Durugbo, C. and Roy, R. (2013) 'Identifying uncertainties for industrial service delivery: A systems approach', International Journal of Production Research, 51(21), pp. 6295-6315. doi: 10.1080/00207543.2013.794316.

Fischer, T. et al. (2010) 'Exploitation or exploration in service business development?', Journal of Service Management, 21(5), pp. 591-624. doi: 10.1108/09564231011079066.

Flyvbjerg, B. (2006) ‘Five Misunderstandings About Case-Study Research', Qualitative Inquiry, 12(2), pp. 219-245. doi: 10.1177/1077800405284363.

Frei, F. X. (2006) 'Breaking the Trade-Off Between Efficiency and Service', Harvard Business Review, 84(11), pp. 92-101.

Galvagno, M. and Dalli, D. (2014) 'Theory of value co-creation: A systematic literature review', Managing Service Quality, 24(6), pp. 643-683. doi: 10.1108/MSQ-09-2013-0187.

Gebauer, H., Haldimann, M. and Saul, C. J. (2017) 'Competing in business-to-business sectors through pay-per-use services', Journal of Service Management, 28(5), pp. 914-935. doi: 10.1108/JOSM-07-2016-0202.

Gibbert, M., Ruigrok, W. and Wicki, B. (2008) 'What passes a rigorous case study?', Strategic Management Journal, 29, pp. 1465-1474. doi: 10.1002/smj.

Grönroos, C. and Helle, P. (2010) ‘Adopting a service logic in manufacturing: Conceptual foundation and metrics for mutual value creation', Journal of Service Management, 21(5), pp. 564-590. doi: 10.1108/09564231011079057.

Hakanen, T. and Jaakkola, E. (2012) 'Co-creating customer-focused solutions within business networks: A service perspective', Journal of Service Management, 23(4), pp. 593-611. doi: $10.1108 / 09564231211260431$.

Hoyer, W. D. et al. (2010) 'Consumer cocreation in new product development', Journal of 
Service Research, 13(3), pp. 283-296. doi: 10.1177/1094670510375604.

Johnsen, T. E. (2009) 'Supplier involvement in new product development and innovation: Taking stock and looking to the future', Journal of Purchasing and Supply Management. Elsevier, 15(3), pp. 187-197. doi: 10.1016/j.pursup.2009.03.008.

Kastalli, I. V. and Van Looy, B. (2013) 'Servitization: Disentangling the impact of service business model innovation on manufacturing firm performance', Journal of Operations Management. Elsevier B.V., 31(4), pp. 169-180. doi: 10.1016/j.jom.2013.02.001.

Kindström, D. and Kowalkowski, C. (2009) 'Development of industrial service offerings: A process framework', Journal of Service Management, 20(2), pp. 156-172. doi:

10.1108/09564230910952753.

Kreye, M. E. et al. (2012) 'Approaches of Displaying Information to Assist Decisions under Uncertainty', Omega - International Journal of Management Science, 40(6), pp. 682-692.

Kreye, M. E. (2016) ‘Employee motivation in Product-Service-System providers’, Production Planning \& Control, 27(15), pp. 1249-1259. doi: 10.1080/09537287.2016.1206219.

Kreye, M. E. (2017a) 'Can you put too much on your plate? Uncertainty exposure in servitized triads', International Journal of Operations \& Production Management. doi: 10.1108/IJOPM-06-2016-0357.

Kreye, M. E. (2017b) 'Relational uncertainty in service dyads', International Journal of Operations \& Production Management, 37(3), pp. 363-381. doi: 10.1108/IJOPM-11-2015-0670.

Kristensson, P., Matthing, J. and Johansson, N. (2008) 'Key strategies for the successful involvement of customers in the co-creation of new technology-based services', International Journal of Service Industry Management, 19(4), pp. 474-491. doi: 10.1108/09564230810891914.

Lariviere, B. and Kandampully, J. (2019) 'Moving forward and making an impact in service research: from research priorities to research methodologies', Journal of Service Management, 
30(5), pp. 521-523. doi: 10.1108/JOSM-10-2019-414.

Lee, H. L. and Schmidt, G. (2017) ‘Using Value Chains to Enhance Innovation', Production and Operations Management, 26(4), pp. 617-632. doi: 10.1111/poms. 12665.

Lewis, M. A. and Brown, A. D. (2012) 'How different is professional service operations management?', Journal of Operations Management, 30(1-2), pp. 1-11. doi: 10.1016/j.jom.2011.04.002.

Lievens, A. and Moenaert, R. K. (2000) 'New Service Teams as Information-Processing Systems', Journal of Service Research, 3(1), pp. 46-65. doi: 10.1177/109467050031004.

Lofberg, N., Witell, L. and Gustafsson, A. (2015) 'Service manoeuvres to overcome challenges of servitisation in a value network', Production Planning and Control, 26(14-15), pp. 1188-1197. doi: 10.1080/09537287.2015.1033491.

Melander, L. and Tell, F. (2014) 'Uncertainty in collaborative NPD: Effects on the selection of technology and supplier', Journal of Engineering and Technology Management - JET-M. Elsevier B.V., 31(1), pp. 103-119. doi: 10.1016/j.jengtecman.2013.10.009.

Mele, C. et al. (2018) 'Shaping service ecosystems: exploring the dark side of agency', Journal of Service Management, 29(4), pp. 521-545. doi: 10.1108/JOSM-02-2017-0026.

Mendes, G. H. S. et al. (2017) 'Uncovering the structures and maturity of the new service development research field through a bibliometric study (1984-2014)', Journal of Service Management, 28(1), pp. 182-223. doi: 10.1108/JOSM-07-2015-0230.

Miles, M. B., Huberman, A. M. and Saldaña, J. (2014) Qualitative Data Analysis: A Methods Sourcebook. 3rd edn. Thousand Oaks, CA, USA: Sage Publications, Inc.

$\mathrm{Ng}$, I. et al. (2012) 'Transitioning from a goods-dominant to a service-dominant logic: Visualising the value proposition of Rolls-Royce', Journal of Service Management, 23(3), pp. 416-439. doi: 10.1108/09564231211248480. 
Nordin, F. et al. (2011) 'The risks of providing services', Journal of Service Management, 22(3), pp. 390-408. doi: 10.1108/09564231111136881.

Nudurupati, S. S. et al. (2016) 'Eight challenges of servitisation for the configuration, measurement and management of organisations', Journal of Service Theory and Practice, 26(6), pp. 745-763. doi: 10.1108/JSTP-02-2015-0045.

O’Connor, G. C. and Rice, M. P. (2013) 'A comprehensive model of uncertainty associated with radical innovation', Journal of Product Innovation Management, 30, pp. 2-18. doi: 10.1111/jpim.12060.

Oertzen, A. S. et al. (2018) 'Co-creating services-conceptual clarification, forms and outcomes', Journal of Service Management, 29(4), pp. 641-679. doi: 10.1108/JOSM-03-20170067.

Pinho, N. et al. (2014) 'Understanding value co-creation in complex services with many actors', Journal of Service Management, 25(4), pp. 470-493. doi: 10.1108/JOSM-02-2014-0055.

Prahalad, C. K. and Ramaswamy, V. (2004) 'Co-creation experiences: The next practice in value creation', Journal of Interactive Marketing, 18(3), pp. 5-14. doi: 10.1002/dir.20015.

Primo, M. A. M. and Amundson, S. D. (2002) 'An exploratory study of the effects of supplier relationships on new product development outcomes', Journal of Operations Management, 20(1), pp. 33-52. doi: 10.1016/S0272-6963(01)00080-8.

Russo-Spena, T. and Mele, C. (2012) “"Five Co-s” in innovating: A practice-based view', Journal of Service Management, 23(4), pp. 527-553. doi: 10.1108/09564231211260404.

Saccani, N., Visintin, F. and Rapaccini, M. (2014) 'Investigating the linkages between service types and supplier relationships in servitized environments', International Journal of Production Economics. Elsevier, 149, pp. 226-238. doi: 10.1016/j.ijpe.2013.10.001.

Sakao, T., Panshef, V. and Dörsam, E. (2009) 'Addressing Uncertainty of PSS for Value- 
Chain Oriented Service Development', in Introduction to Product/Service-System Design.

Springer London Dordrecht Heidelberg New York, pp. 137-159. doi: 10.1007/978-1-84882-909$1 \_12$.

Sicotte, H. and Bourgault, M. (2008) 'Dimensions of uncertainty and their moderating effect on new product development project performance', $R \& D$ Management, 38(5), pp. 468-479. doi: 10.1111/j.1467-9310.2008.00531.x.

Smith, L., Maull, R. and Ng, I. C. L. (2014) 'Servitization and operations management: a service dominant-logic approach', International Journal of Operations \& Production Management, 34(2), pp. 242-269. doi: 10.1108/JJOPM-02-2011-0053.

Strauss, A. and Corbin, J. M. (1998) Basics of Qualitative Research. New York, New York, USA: SAGE Publications.

Tatikonda, M. V and Rosenthal, S. R. (2000) 'Successful execution of product development projects : Balancing firmness and flexibility in the innovation process', Journal of Operations Management, 18, pp. 401-425.

Vargo, S. L. and Lusch, R. F. (2008) 'Service-dominant logic: Continuing the evolution', Journal of the Academy of Marketing Science, 36(1), pp. 1-10. doi: 10.1007/s11747-007-0069-6.

Verleye, K. (2019) 'Designing, writing-up and reviewing case study research: an equifinality perspective', Journal of Service Management, 30(5), pp. 549-576. doi: 10.1108/JOSM-08-20190257.

Wise, R. and Baumgartner, P. (1999) 'Go Downstream: The New Profit Imperative in Manufacturing.', Harvard Business Review, 77(5), pp. 133-141.

Yin, R. K. (2009) Case study research: Design and methods. 4th edn. London and Singapore: SAGE Publications.

Zhang, Y., Gregory, M. and Neely, A. (2016) 'Global engineering services: Shedding light 
on network capabilities', Journal of Operations Management. Elsevier Ltd, 42-43, pp. 80-94. doi: 10.1016/j.jom.2016.03.006. 


\section{Appendix}

\section{Questionnaire}

\section{Engineering service (ES) of the company:}

1. Can you explain the concept of your ES?

\section{Uncertainty in the ES development process:}

2. Can you summarize for me the major steps of your development process for the ES?

3. What went especially well during the development project of the ES? Why?

4. What went especially not so well during the development project of the ES? Why? For each instance: How did you manage it? How strong was the impact? How predictable/anticipated was it to happen?

4.1. Environmental challenges

4.1.1. Customers, competitors, pricing, revenue model, demand changes, changes in legislation, competitor's actions, technological development, political developments)

4.2. Technical challenges

4.2.1. Product, Service, System integration

4.3. Resource challenges

4.3.1. Capabilities, Information, Financing, Interdependencies of Projects, macroeconomic resources (energy, cost of licensing, raw materials)

4.4. Organizational challenges

4.4.1. Intersection with functions or processes, internal stakeholders (e.g. acceptance of "service-culture", risk aversion of decision makers, varying uncertainty perception, strategic ambiguity in the prioritization of the project...), project planning + execution (e.g. goal definition, determination of methods, design of experiments ( simulation of lifecycle), alignment of sub-projects, forecasting...)

4.5. Relational challenges

4.5.1. Which stakeholders?

4.5.2. Relationship: formal/informal, split of costs and risks, Intellectual property, Quality and timing of agreed delivery, availability and reliability, hidden agendas, commitment, actual capabilities, management of uncertainties, bankruptcy...

\section{Additional information:}

5. In retrospective: What should have been done differently and how? (lessons learned)

6. Is there anything else you would like to add or clarify? And could you point out any additional information that would support my research project? 


\section{Figures and Tables}

Operational independence (OI)
The majority of the tasks are
completed in-house of the focal firm,
with some non-critical input from the
supplier.
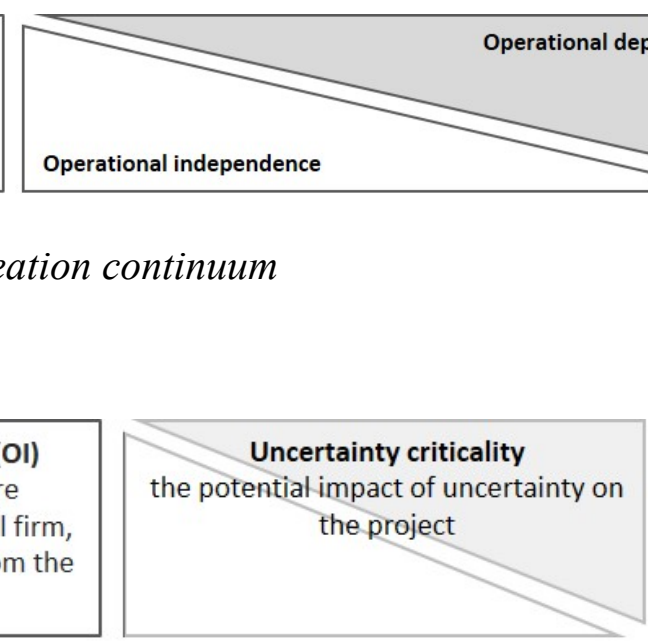

Operational independence (OI)

The majority of the tasks are completed in-house of the focal firm, with some non-critical input from the supplier.

\section{Environmental uncertainty \\ - Competitors \\ - Customers}

\section{Technical uncertainty \\ - Commercial scoping \\ - Modeling and forecasting \\ - Rollout across the portfolio}

Organizational uncertainty

- Definition of functions and processes

- Pricing

- Reorganization

- Long internal processes

- Cost conscious culture

- Highly independent subsidiaries

- Internationality

Resource uncertainty

- Ability to execute the service

- Resource availability of specialized knowledge

- Quality of the deliverable

- Tool suitability

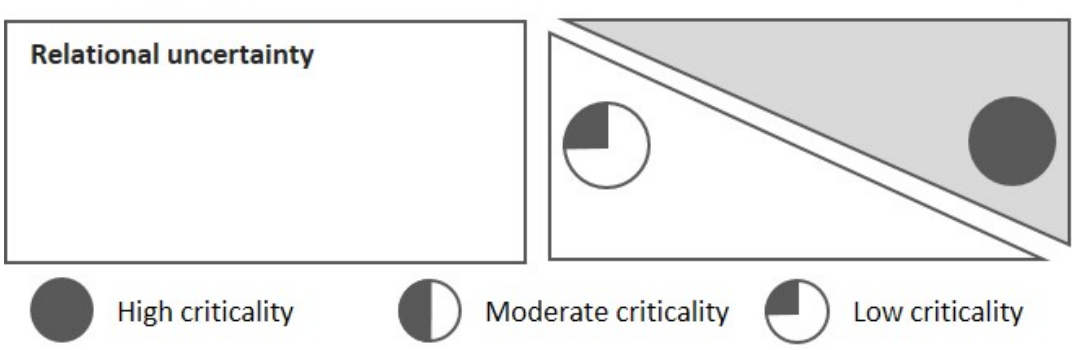

Operational dependence (OD)

Supplier contributes many and critical tasks to the joint development with the focal firm.
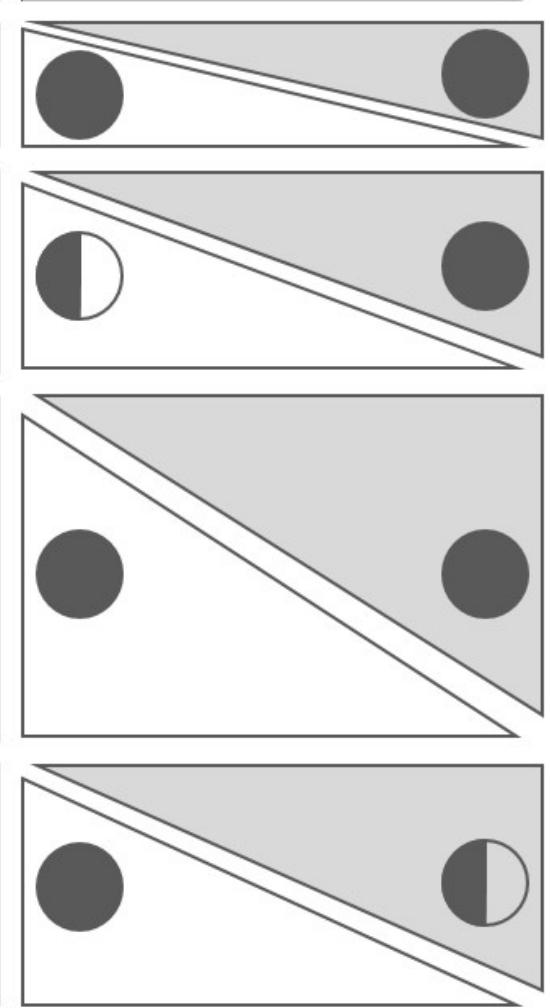

Environmental uncertainty

- Competitors

- Customers

Technical uncertainty

- Commercial scoping

- Modeling and forecasting

- Rollout across the portfolio

- Interfaces with existing system

Organizational uncertainty

- Definition of functions and processes

- Pricing

- Reorganization

- Long internal processes

- Lack of service culture

- Overlap with existing portfolio

- Project planning

Resource uncertainty

- Ability to execute the service

- Resource availability of specialized knowledge

- Quality of the deliverable

Relational uncertainty

- Large stakeholder network

- Conflict resolution with supplier

- Hidden agendas of supplier

- Supplier capabilities

- Supplier communication

Figure 2: Framework of uncertainty in supplier co-creation of engineering-service development 
Table 1: Uncertainty in the service management and NPD literature

\begin{tabular}{|c|c|c|c|}
\hline Reference & Literature & Uncertainty type & Definition \\
\hline (Cheng and Krumwiede, 2017) & $\begin{array}{l}\text { Service } \\
\text { management }\end{array}$ & $\begin{array}{l}\text { Environmental } \\
\text { uncertainty } \\
\text { - Organizational } \\
\text { uncertainty } \\
\text { (referred as } \\
\text { strategic } \\
\text { flexibility) }\end{array}$ & $\begin{array}{l}\text { - Environmental uncertainty: rate of } \\
\text { change and level of instability in the } \\
\text { business environment } \\
\text { - Organizational uncertainty: the ability } \\
\text { to precipitate intentional changes and } \\
\text { adapt to environmental changes } \\
\text { through continuous changes in current } \\
\text { strategic actions, asset deployment, } \\
\text { and investment strategies }\end{array}$ \\
\hline (Kreye, 2017b) & $\begin{array}{l}\text { Service } \\
\text { management }\end{array}$ & $\begin{array}{l}\text { - Environmental } \\
\text { uncertainty } \\
\text { - Organizational } \\
\text { uncertainty } \\
\text { - Relational } \\
\text { uncertainty }\end{array}$ & $\begin{array}{l}\text { - Environmental uncertainty: } \\
\text { unpredictability of a company's } \\
\text { external environment } \\
\text { - Organizational uncertainty: internal } \\
\text { sources of uncertainty arising from } \\
\text { gap between the capabilities an } \\
\text { organization possesses and the } \\
\text { capabilities it needs } \\
\text { - Relational uncertainty: the inability to } \\
\text { predict and explain others' actions }\end{array}$ \\
\hline (Erkoyuncu et al., 2011) & $\begin{array}{l}\text { Service } \\
\text { management }\end{array}$ & $\begin{array}{l}\text { - Environmental } \\
\text { uncertainty } \\
\text { (referenced as } \\
\text { demand } \\
\text { uncertainty) } \\
\text { - Resource } \\
\text { uncertainty } \\
\text { (referenced as } \\
\text { supply } \\
\text { uncertainty) } \\
\end{array}$ & $\begin{array}{l}\text { - Environmental uncertainty: } \\
\text { unpredictability of the demand for the } \\
\text { offering considering the long life } \\
\text { cycles } \\
\text { - Resource uncertainty: managing } \\
\text { resource availability, capacity and } \\
\text { capability }\end{array}$ \\
\hline (Lievens and Moenaert, 2000) & $\begin{array}{l}\text { Service } \\
\text { management }\end{array}$ & $\begin{array}{l}\text { Environmental } \\
\text { uncertainty } \\
\text { (referenced as } \\
\text { customer, } \\
\text { competitor, and } \\
\text { technological } \\
\text { uncertainty) } \\
\text { - Resource } \\
\text { uncertainty } \\
\end{array}$ & $\begin{array}{l}\text { - Environmental uncertainty: } \\
\text { unpredictability of user needs, } \\
\text { competitive actions, and } \\
\text { technological developments } \\
\text { - Resource uncertainty: appropriateness } \\
\text { of financial, technical, and human } \\
\text { resources }\end{array}$ \\
\hline (Sicotte and Bourgault, 2008) & NPD & $\begin{array}{l}\text { - Environmental } \\
\text { uncertainty } \\
\text { - Organizational } \\
\text { uncertainty } \\
\text { (referenced as task } \\
\text { variety) } \\
\text { - Technical } \\
\text { uncertainty } \\
\text { (referenced as task } \\
\text { analyzability) } \\
\end{array}$ & $\begin{array}{l}\text { - Environmental uncertainty: rapid } \\
\text { changes in the external environment } \\
\text { - Organizational uncertainty: } \\
\text { organizational interdependence and } \\
\text { variability } \\
\text { - Technical uncertainty: complexity } \\
\text { and lack of knowledge of the } \\
\text { variables and rules concerning project } \\
\text { specification }\end{array}$ \\
\hline (Chen et al., 2005) & NPD & $\begin{array}{l}\text { - Market uncertainty } \\
\text { - Technical } \\
\text { uncertainty }\end{array}$ & $\begin{array}{l}\text { - Market uncertainty: ambiguity about } \\
\text { the type and extent of customer needs } \\
\text { that can be satisfied }\end{array}$ \\
\hline
\end{tabular}




\begin{tabular}{|c|c|c|c|}
\hline & & & $\begin{array}{l}\text { - Technical uncertainty: degree of } \\
\text { familiarity with the given technology } \\
\text { or degree of change in the } \\
\text { technologies relative to products } \\
\text { developed or manufactured by the } \\
\text { company }\end{array}$ \\
\hline (O’Connor and Rice, 2013) & NPD & $\begin{array}{l}\text { - } \text { Market uncertainty } \\
\text { - Technical } \\
\text { uncertainty } \\
\text { - Resource } \\
\text { uncertainty } \\
\text { - Organizational } \\
\text { uncertainty }\end{array}$ & $\begin{array}{l}\text { - Market uncertainty: degree to which } \\
\text { customer needs are well understood } \\
\text { and converted into a market } \\
\text { application, as well as appropriate } \\
\text { markets are defined and a suitable } \\
\text { business model chosen } \\
\text { - Technical uncertainty: degree to } \\
\text { which the underlying scientific } \\
\text { knowledge is well understood and } \\
\text { can be converted into a reliable, cost- } \\
\text { efficient technology platform that is } \\
\text { manufacturable } \\
\text { - Resource uncertainty: the ability to } \\
\text { attract the required resources } \\
\text { (financial and competency based) } \\
\text { - Organizational uncertainty: } \\
\text { organizational dynamism }\end{array}$ \\
\hline (Melander and Tell, 2014) & NPD & 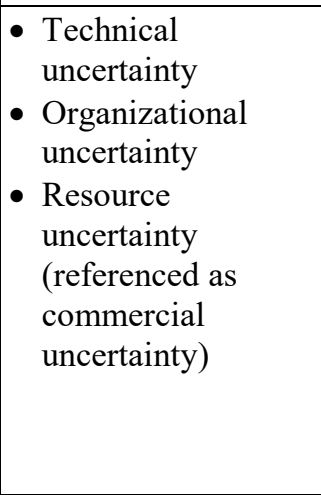 & $\begin{array}{l}\text { Technical uncertainty: techno- } \\
\text { paradigmatic and complexity-related } \\
\text { problems, in which discontinuous } \\
\text { change and high complexity may call } \\
\text { for flexibility } \\
\text { - Organizational uncertainty: problems } \\
\text { of inter- and intra-organizational fit, } \\
\text { where low fit may necessitate } \\
\text { openness to flexibility } \\
\text { - Resource uncertainty: problems } \\
\text { regarding cost, supplier (resource) } \\
\text { appropriation }\end{array}$ \\
\hline (Tatikonda and Rosenthal, 2000) & NPD & $\begin{array}{l}\text { - Technical } \\
\text { uncertainty } \\
\text { (referenced as task } \\
\text { uncertainty) }\end{array}$ & $\begin{array}{l}\text { - Technical uncertainty: lack of } \\
\text { experience with the product and } \\
\text { process technologies they intend to } \\
\text { employ in or with a product } \\
\text { development effort }\end{array}$ \\
\hline
\end{tabular}


Table 2: Conceptual framework of uncertainty in engineering-service development

\begin{tabular}{|c|c|c|}
\hline $\begin{array}{l}\text { Uncertainty } \\
\text { Type }\end{array}$ & Definition & Operationalization for engineering services (ESs) \\
\hline $\begin{array}{l}\text { Environmental } \\
\text { uncertainty }\end{array}$ & $\begin{array}{l}\text { Unpredictability of the external } \\
\text { environment } \\
\text { (Sicotte and Bourgault, 2008) }\end{array}$ & $\begin{array}{l}\text { - Lack of understanding customer needs } \\
\text { (Kristensson et al., 2008) } \\
\text { - Unpredictability of competitor's behavior } \\
\text { (Fischer et al., 2010) } \\
\text { - Technological developments } \\
\text { (Lievens and Moenaert, 2000) } \\
\text { - Macro-economic or legal developments (Kreye, 2017a) }\end{array}$ \\
\hline $\begin{array}{l}\text { Technical } \\
\text { uncertainty }\end{array}$ & $\begin{array}{l}\text { Lack of experience with the } \\
\text { product and process technologies } \\
\text { they intend to employ in or with } \\
\text { a product development effort } \\
\text { (Tatikonda and Rosenthal, 2000) }\end{array}$ & $\begin{array}{l}\text { - Lack of engineering expertise for the design and } \\
\text { development of the product (O'Connor and Rice, 2013) } \\
\text { - Lack of expertise for the design and development of the } \\
\text { service element (Nordin et al., 2011) } \\
\text { - Technical complexity regarding the systemic integration } \\
\text { of the product and the service element } \\
\text { (Gebauer } \text { et al., 2017) }\end{array}$ \\
\hline $\begin{array}{l}\text { Organizational } \\
\text { uncertainty }\end{array}$ & $\begin{array}{l}\text { Organizational dynamism within } \\
\text { the organization (incl. the } \\
\text { development team and the wider } \\
\text { organization) } \\
\text { (O'Connor and Rice, 2013) }\end{array}$ & $\begin{array}{l}\text { - Organizational change (O’Connor and Rice, 2013) } \\
\text { - Unknown change in the organizational architecture } \\
\text { (processes and structure) to develop and prepare for ES } \\
\text { delivery (Nudurupati et al., 2016) } \\
\text { - Pricing strategy (Nudurupati et al., 2016) } \\
\text { - Transition towards a service culture (Ng et al., 2012) }\end{array}$ \\
\hline $\begin{array}{l}\text { Resource } \\
\text { uncertainty }\end{array}$ & $\begin{array}{l}\text { Appropriateness of financial, } \\
\text { technical, and human resources } \\
\text { (Lievens and Moenaert, 2000) }\end{array}$ & $\begin{array}{l}\text { - Lack of skills and capabilities for the ES development, as } \\
\text { well as lack of staff for the project and/or the execution } \\
\text { (Fischer et al., 2010) } \\
\text { - Lack of financial, technical and human resources } \\
\text { (Lievens and Moenaert, 2000) }\end{array}$ \\
\hline $\begin{array}{l}\text { Relational } \\
\text { uncertainty }\end{array}$ & $\begin{array}{l}\text { The inability to predict and } \\
\text { explain others' actions } \\
\text { (Kreye, 2017a) }\end{array}$ & $\begin{array}{l}\text { - Conflict, ambiguity, opportunism, and conformity issues } \\
\text { (Mele et al., 2018) } \\
\text { - Lack of trust and commitment to the development from a } \\
\text { specific partner (Kreye, 2017b) } \\
\text { - Differing level of goal alignment, differing social, legal } \\
\text { and/or regulatory standards (Kreye, 2017a) }\end{array}$ \\
\hline
\end{tabular}


Table 3: Summary of the data

\begin{tabular}{|c|c|c|}
\hline & Case 1 & Case 2 \\
\hline Sector & Construction equipment & Food equipment \\
\hline $\begin{array}{l}\text { Engineering } \\
\text { service (ES) }\end{array}$ & $\begin{array}{l}\text { 3D-scanning, analyzing scans, forecasting wear } \\
\text { trend, optimizing wear part design, supply and } \\
\text { installation of adjusted wear parts based on a } \\
\text { condition monitoring system. }\end{array}$ & $\begin{array}{l}\text { Maintenance, monitoring, analysis, and } \\
\text { optimization based on a condition monitoring } \\
\text { system. }\end{array}$ \\
\hline Co-creation & Operationally independent (OI) & Operationally dependent (OD) \\
\hline $\begin{array}{l}\text { Time spent } \\
\text { on site }\end{array}$ & 2 weeks & 1 week \\
\hline Interviewees & $\begin{array}{l}10 \text { Interviews } \\
\text { - Project manager } \\
\text { - Sales engineer } \\
\text { - Development engineer } 1 \\
\text { - Development engineer } 2 \\
\text { - Customer service sales manager } \\
\text { - Chief engineer } \\
\text { - Innovation manager } \\
\text { - Key account manager } \\
\text { - Launch manager } \\
\text { Additionally: } \\
\text { - Participation in } 1 \text { monthly meeting }\end{array}$ & $\begin{array}{l}\text { Interviews } \\
\text { - Project manager } \\
\text { - Product launch manager } \\
\text { - Service product manager } 1 \\
\text { - Service product manager } 2 \\
\text { - IT Product manager } \\
\text { - Head of service product management } \\
\text { - IT } 2^{\text {nd }} \text { level support } \\
\text { - Technical project manager from supplier } 2\end{array}$ \\
\hline $\begin{array}{l}\text { Archival } \\
\text { Data }\end{array}$ & $\begin{array}{l}\text { - Monthly meeting minutes } \\
\text { - Status reports } \\
\text { - Business case } \\
\text { - Launch plan } \\
\text { - Project plan } \\
\text { - Project management dashboard } \\
\text { - Marketing material (flyers, video) } \\
\text { - Gate meeting presentations } \\
\text { - Business case of the pilot study } \\
\text { - Development process }\end{array}$ & $\begin{array}{l}\text { - Steering committee presentations } \\
\text { - Kick-off presentation } \\
\text { - Development process } \\
\text { - Overview of the intranet of the project } \\
\text { - Service level agreements (SLA's) } \\
\text { - Project dashboard } \\
\text { - ES outline }\end{array}$ \\
\hline
\end{tabular}


Table 4: Coding examples

\begin{tabular}{|c|c|c|c|}
\hline Exemplar quotes & $\begin{array}{l}\text { First order codes } \\
\text { (case-specific) }\end{array}$ & $\begin{array}{l}\text { Second order } \\
\text { codes (cross-case) }\end{array}$ & $\begin{array}{l}\text { Aggregate } \\
\text { concepts }\end{array}$ \\
\hline \multicolumn{4}{|l|}{ Uncertainty instances } \\
\hline $\begin{array}{l}\text { Project manager, Case 2: "Especially in May } \\
\text { there will come this EU Data Protection } \\
\text { Directive. There we are still trying to solve that } \\
\text { issue now." }\end{array}$ & $\begin{array}{l}\text { Unknown impact of } \\
\text { European data } \\
\text { protection law }\end{array}$ & $\begin{array}{l}\text { Changing legal } \\
\text { setting }\end{array}$ & $\begin{array}{l}\text { Environmental } \\
\text { uncertainty }\end{array}$ \\
\hline $\begin{array}{l}\text { Project manager, Case 1: "And there [product 1] } \\
\text { we are not going so much into detail as we are in } \\
\text { [product 2]. And that degree of accuracy, that } \\
\text { requires a lot of data points which we could not } \\
\text { handle [initially]." }\end{array}$ & $\begin{array}{l}\text { Technical differences } \\
\text { between machines }\end{array}$ & $\begin{array}{l}\text { Rollout across the } \\
\text { portfolio }\end{array}$ & $\begin{array}{l}\text { Technical } \\
\text { uncertainty }\end{array}$ \\
\hline $\begin{array}{l}\text { Project manager, Case 1: "it is a big organization } \\
\text { and we don't know what is in all corners... We } \\
\text { did not know that [South America] was [already] } \\
\text { doing this [ES]." }\end{array}$ & $\begin{array}{l}\text { Uncertainty about } \\
\text { existing knowledge } \\
\text { in company }\end{array}$ & $\begin{array}{l}\text { Highly independent } \\
\text { subsidiaries }\end{array}$ & $\begin{array}{l}\text { Organizational } \\
\text { uncertainty }\end{array}$ \\
\hline $\begin{array}{l}\text { Sales engineer, Case 1: "the capacity of people } \\
\text { we have, that actually know how to use the } \\
\text { software, that is a limitation, because it takes a } \\
\text { lot to reach those results" }\end{array}$ & $\begin{array}{l}\text { Capacity for use of } \\
\text { the software }\end{array}$ & $\begin{array}{l}\text { Ability to execute } \\
\text { the service }\end{array}$ & $\begin{array}{l}\text { Resource } \\
\text { uncertainty }\end{array}$ \\
\hline $\begin{array}{l}\text { IT product manager, Case } 2: \text { "Well, they did } \\
\text { deliver, but not what we wanted. Only what } \\
\text { served their standard development. And that } \\
\text { happened, even though we had clearly specified } \\
\text { the requirements in the beginning." }\end{array}$ & Hidden agendas & $\begin{array}{l}\text { Supplier } \\
\text { collaboration }\end{array}$ & $\begin{array}{l}\text { Relational } \\
\text { uncertainty }\end{array}$ \\
\hline \multicolumn{4}{|l|}{ Criticality } \\
\hline $\begin{array}{l}\text { Service product manager 2, Case 2: "Because if } \\
\text { you don't handle the NAA's [Network Access } \\
\text { Agreements] properly, the [engineering-] service } \\
\text { cannot be provided at all!" }\end{array}$ & High criticality & $\mathrm{N} / \mathrm{A}$ & $\mathrm{N} / \mathrm{A}$ \\
\hline $\begin{array}{l}\text { Head of service product management, Case } 2 \text { : "It } \\
\text { took away focus from nearly all people. Because } \\
\text { the majority of the people got a new position or a } \\
\text { new working environment. And that takes time. } \\
\text { Until it really works you are three years further." }\end{array}$ & High criticality & N/A & $\mathrm{N} / \mathrm{A}$ \\
\hline $\begin{array}{l}\text { Key account manager, Case 1: "it took three } \\
\text { months to figure that out." }\end{array}$ & Moderate criticality & N/A & N/A \\
\hline $\begin{array}{l}\text { Service product manager 1, Case 2: "Of course } \\
\text { this new "Zeitgeist" increases the pressure on us } \\
\text { because everyone is doing [ES] now." }\end{array}$ & Moderate criticality & N/A & $\mathrm{N} / \mathrm{A}$ \\
\hline $\begin{array}{l}\text { Chief engineer, Case 1: "We took the learnings } \\
\text { from my [product 1] project [for the product } 2 \\
\text { project]... You need to handle the scan slightly } \\
\text { different, but that's pretty straightforward when } \\
\text { you see the machine." }\end{array}$ & Low criticality & N/A & $\mathrm{N} / \mathrm{A}$ \\
\hline $\begin{array}{l}\text { Service product manager } 1 \text {, Case } 2 \text { : "then that } \\
\text { led to slight delays. At the end of the day we got } \\
\text { a couple more people... }\end{array}$ & Low criticality & $\mathrm{N} / \mathrm{A}$ & $\mathrm{N} / \mathrm{A}$ \\
\hline
\end{tabular}




\section{Table 5: Uncertainty instances Case 1}

\begin{tabular}{|c|c|c|}
\hline Uncertainty instances & Uncertainty description & Uncertainty criticality \\
\hline \multicolumn{2}{|c|}{ Environmental uncertainty } & High criticality \\
\hline $\begin{array}{l}\text { Competitors } \\
\text { uncertainty through } \\
\text { strong increase in } \\
\text { competition }\end{array}$ & $\begin{array}{l}\text { Customer service sales manager: } \\
\text { "[Competitor 1] will offer the service... } \\
\text { [Competitor 2] and [Competitor 3] are } \\
\text { doing the same thing..." }\end{array}$ & $\begin{array}{l}\text { High criticality } \\
\text { This created very high time pressure for the } \\
\text { development team to be able to stay competitive on } \\
\text { the market. }\end{array}$ \\
\hline $\begin{array}{l}\text { Customer } \\
\text { uncertainty around the } \\
\text { actual value for the } \\
\text { customer }\end{array}$ & $\begin{array}{l}\text { Monthly meeting minutes: "Clients are } \\
\text { informing us that "[case company 1] should } \\
\text { include service" and [sales manager] } \\
\text { emphasized that [ES] is required just to be } \\
\text { able to maintain the existing market share." }\end{array}$ & $\begin{array}{l}\text { High criticality } \\
\text { ES is essential to retain current customers. } \\
\text { Key account manager: "Without the [ES], you would } \\
\text { create a perception with your client that you are not } \\
\text { at the cutting edge of supporting your wear lining } \\
\text { products as well as the competition. So we are } \\
\text { playing catch up... I would say it has very high } \\
\text { priority." }\end{array}$ \\
\hline \multicolumn{2}{|l|}{ Technical uncertainty } & Moderate criticality \\
\hline $\begin{array}{l}\text { Commercial scoping } \\
\text { uncertainty arising from } \\
\text { attractive and } \\
\text { competitive commercial } \\
\text { scoping }\end{array}$ & $\begin{array}{l}\text { Project manager: "[Selling the service as } \\
\text { part of the wear part sales] is also the } \\
\text { strategy in the North American market. In } \\
\text { South America, we have already started } \\
\text { doing this as separate service jobs } \\
\text { [independent from the wear part sales]... } \\
\text { There is money in this as well, but not in } \\
\text { the same scale as selling the [wear parts]." }\end{array}$ & $\begin{array}{l}\text { Low criticality } \\
\text { This created a time delay due to the ambivalence } \\
\text { about the precise scoping of the ES: should it be a } \\
\text { stand-alone offering, or sold in combination with the } \\
\text { wear parts? }\end{array}$ \\
\hline $\begin{array}{l}\text { Modeling and } \\
\text { forecasting } \\
\text { uncertainty about the } \\
\text { forecasting accuracy }\end{array}$ & $\begin{array}{l}\text { Project manager: "we were worried about } \\
\text { the accuracy of what we are measuring... } \\
\text { So in the [product 1] the [ES predictions] } \\
\text { we would have not be able to project when } \\
\text { the [wear parts] should be changed. And } \\
\text { there the prediction should be right. This is } \\
\text { of course very important." }\end{array}$ & $\begin{array}{l}\text { High criticality } \\
\text { High impact of imprecise predictions of ES on } \\
\text { overall profitability of ES. } \\
\text { Project manager: "And there, the stakes are high if } \\
\text { we predict this wrong. But we can see that we can at } \\
\text { least make the same accuracy as the } 3 \text { rd party. But } \\
\text { still, there is always a risk you can say." }\end{array}$ \\
\hline $\begin{array}{l}\text { Rollout across the } \\
\text { portfolio } \\
\text { uncertainty arising from } \\
\text { changing requirements } \\
\text { for different machines }\end{array}$ & $\begin{array}{l}\text { Project manager: "For [product 1] it seemed } \\
\text { to be ok. [Product 1] has a big surface and it } \\
\text { not so important to be within the mm } \\
\text { accuracy. But for [product 2] there it is } \\
\text { another story. We were not aware of it." }\end{array}$ & $\begin{array}{l}\text { Low criticality } \\
\text { Different products, but intuitive adjustments. } \\
\text { Chief engineer: "In the [product 1] you take the } \\
\text { [wear part] out when you [perform ES]. In the } \\
\text { [product 2] you don't, you scan the [wear parts] } \\
\text { while it is sitting inside. So it is slightly different but } \\
\text { ok. It just comes natural." }\end{array}$ \\
\hline \multicolumn{2}{|l|}{ Organizational uncertainty } & High criticality \\
\hline $\begin{array}{l}\text { Definition of functions } \\
\text { and processes } \\
\text { uncertainty about the } \\
\text { functions and processes } \\
\text { for the execution }\end{array}$ & $\begin{array}{l}\text { Customer service sales manager: "It is a } \\
\text { matter of defining these new internal } \\
\text { processes and functions, who is supposed to } \\
\text { take it over? That hasn't really been } \\
\text { considered in the first idea what it would } \\
\text { mean to do that. That is correct." }\end{array}$ & $\begin{array}{l}\text { High criticality } \\
\text { This created several months delay of the whole } \\
\text { development project. }\end{array}$ \\
\hline $\begin{array}{l}\text { Pricing } \\
\text { uncertainty about pricing } \\
\text { of the offering in order to } \\
\text { keep it competitive and } \\
\text { profitable }\end{array}$ & $\begin{array}{l}\text { Customer service sales manager: "So we } \\
\text { first have to understand our internal cost to } \\
\text { understand what it's valued is, and then } \\
\text { when we go to our customers" }\end{array}$ & $\begin{array}{l}\text { Low criticality } \\
\text { Some experience with the pricing in-house. } \\
\text { Key account manager: "But basically [we have to } \\
\text { meet] what the competition is charging, he [pricing } \\
\text { employee] is referencing that." }\end{array}$ \\
\hline $\begin{array}{l}\text { Reorganization } \\
\text { uncertainty about } \\
\text { organizational and } \\
\text { project impact of the } \\
\text { reorganization }\end{array}$ & $\begin{array}{l}\text { Project manager: "Our R\&D will be split } \\
\text { into [part 1] and [part 2], and [development } \\
\text { engineer 1] will go to [part 1], which means } \\
\text { that he will have to leave our project } \\
\text { because we are in the [part 2] with the } \\
\text { [ES]." }\end{array}$ & $\begin{array}{l}\text { High criticality } \\
\text { Entire ES development depends on availability of } \\
\text { expertise of a single person. } \\
\text { Project manager: "So actually we only have } \\
\text { [development engineer 1] who can do this [ES } \\
\text { modeling and forecasting]... so to completely loose } \\
\text { him is tough." }\end{array}$ \\
\hline
\end{tabular}




\begin{tabular}{|c|c|c|}
\hline $\begin{array}{l}\text { Long internal processes } \\
\text { uncertainty about the } \\
\text { availability of resources } \\
\text { limited through time } \\
\text { consuming approval } \\
\text { processes }\end{array}$ & $\begin{array}{l}\text { Project manager: "So we had to buy the } \\
\text { new software, but before buying that there } \\
\text { were some procedures that we had to } \\
\text { follow, so we had to evaluate a lot... That } \\
\text { took us a lot of time." }\end{array}$ & $\begin{array}{l}\text { High criticality } \\
\text { Strong time delay through lengthy processes. } \\
\text { Development engineer } 1: \text { "We have a process for } \\
\text { buying a new software. So [that] it is very tough. If } \\
\text { you want to use the system and buy a license, it will } \\
\text { take rather } 2-3 \text { months. So this is a difficulty from } \\
\text { the organization." }\end{array}$ \\
\hline $\begin{array}{l}\text { Cost conscious culture } \\
\text { uncertainty about the } \\
\text { ability to execute the } \\
\text { project }\end{array}$ & $\begin{array}{l}\text { Key account manager: "They want to keep } \\
\text { the team as lean as possible." }\end{array}$ & $\begin{array}{l}\text { High criticality } \\
\text { Strong time delay until new staff for ES execution } \\
\text { was available due to cost cutting barriers. } \\
\text { Innovation manager: "we can't support the service } \\
\text { without having people that can do it...[but] they } \\
\text { have to justify new hiring... } \\
\text { up-fronen though we try to be }\end{array}$ \\
\hline $\begin{array}{l}\text { Highly independent } \\
\text { subsidiaries } \\
\text { uncertainty arising from } \\
\text { the knowledge and } \\
\text { offerings available in the } \\
\text { subsidiaries }\end{array}$ & $\begin{array}{l}\text { Project manager: "Because if we have had a } \\
\text { very good cross border cooperation... we } \\
\text { would have known that [subsidiary 1] tried } \\
\text { with the [new] software [, which would } \\
\text { have resolved "modeling and forecasting" } \\
\text { uncertainty]. So it is a big organization and } \\
\text { we don't know what is in all corners... and } \\
\text { we are still missing something." }\end{array}$ & $\begin{array}{l}\text { Moderate criticality } \\
\text { This created additional costs of redundant work as } \\
\text { the development project team discovered only after } \\
\text { several months that some parts of the organization } \\
\text { (South America) were already performing the ES in } \\
\text { a slightly different way and that the team could learn } \\
\text { from them. }\end{array}$ \\
\hline $\begin{array}{l}\text { Internationality } \\
\text { uncertainty arising } \\
\text { through the coordination } \\
\text { of a highly international } \\
\text { team }\end{array}$ & $\begin{array}{l}\text { Project manager: "If you want to have a } \\
\text { meeting with the program manager in } \\
\text { [USA] and our post-processing engineers in } \\
\text { India that will then be a meeting for the } \\
\text { Indian guys in the evening, while in [USA] } \\
\text { it is in the morning. And that is challenging } \\
\text { because the Indian guys to not always have } \\
\text { internet at home, so that is difficult." }\end{array}$ & $\begin{array}{l}\text { High criticality } \\
\text { This created high added complexity and eventually a } \\
\text { time delay due to a multitude of timely disturbances } \\
\text { such as e.g. lacking availability for the meetings due } \\
\text { to travelling staff. }\end{array}$ \\
\hline \multicolumn{2}{|l|}{ Resource uncertainty } & High criticality \\
\hline $\begin{array}{l}\text { Ability to execute the } \\
\text { service } \\
\text { uncertainty about the } \\
\text { responsibility for the } \\
\text { service execution and } \\
\text { training of staff }\end{array}$ & $\begin{array}{l}\text { Chief engineer: "we don't have any staff to } \\
\text { do it [the execution of the ES]. Everyone is } \\
\text { busy and nobody has the time to put up the } \\
\text { people to go to the training and to actually } \\
\text { do this work." }\end{array}$ & $\begin{array}{l}\text { High criticality } \\
\text { Strong delay because ES could not be executed } \\
\text { without trained staff. } \\
\text { Launch manager: " } 4 \text { months delay due to all the } \\
\text { technical problems with the software [resource } \\
\text { uncertainty "Tool suitability"], and another } 2 \text { months } \\
\text { delay for the training of the service guys." }\end{array}$ \\
\hline $\begin{array}{l}\text { Resource availability of } \\
\text { specialized knowledge } \\
\text { uncertainty about the } \\
\text { existence and availability } \\
\text { of specialized skills }\end{array}$ & $\begin{array}{l}\text { Development engineer } 2: \text { "The most serious } \\
\text { problems were the planning and to } \\
\text { somehow achieve staffing of specific } \\
\text { people... for the development of the } \\
\text { project... We must fulfill both functions } \\
\text { [daily operations and the project] to achieve } \\
\text { the end of this project..." }\end{array}$ & $\begin{array}{l}\text { High criticality } \\
\text { ES could not be sold without competent sales staff } \\
\text { promoting it. } \\
\text { Key account manager: "I would say that our biggest } \\
\text { delay that far is having sales people... There are only } \\
\text { very few in the world [who have the relevant } \\
\text { knowledge]. And these guys are very loyal and } \\
\text { spend almost all of their life at their company. } \\
\text { Because you can't just change because you lose } \\
\text { credibility." }\end{array}$ \\
\hline $\begin{array}{l}\text { Quality of deliverable } \\
\text { (from suppliers) } \\
\text { uncertainty arising from } \\
\text { the quality of the } \\
\text { partner's deliverable }\end{array}$ & $\begin{array}{l}\text { Project manager: "... we get a result which } \\
\text { is not similar to what we expect... But, then } \\
\text { we found out that the previous [software] } \\
\text { version [from supplier 1] could make the } \\
\text { calculations actually correctly... So it turns } \\
\text { out that this [software] version of } 2018 \text { is } \\
\text { not correct in calculating..." }\end{array}$ & $\begin{array}{l}\text { Low criticality } \\
\text { Low quality deliverable which challenged the ES } \\
\text { development. } \\
\text { Project manager: "So I think it has maybe taken us } 3 \\
\text { weeks to find that out. Before we went back to the } \\
\text { previous version." }\end{array}$ \\
\hline $\begin{array}{l}\text { Tool suitability } \\
\text { uncertainty around the } \\
\text { suitability of the software } \\
\text { used for the analysis }\end{array}$ & $\begin{array}{l}\text { Monthly meeting minutes: "A major } \\
\text { obstacle has been reached in the post- } \\
\text { processing when using [software } 1 \text { and } 2] \ldots \\
\text { The graphical representation using } \\
\text { [software } 1 \text { and 2] is quite blurry and } \\
\text { clearly inferior quality compared to the }\end{array}$ & $\begin{array}{l}\text { High criticality } \\
\text { Without the required tool, the ES could not have } \\
\text { been offered. } \\
\text { Key account manager: "It would have been a } \\
\text { showstopper. We would not have any other tool to } \\
\text { do the forecasting of the [wear parts] in the [product }\end{array}$ \\
\hline
\end{tabular}




\begin{tabular}{|l|l|l|}
\hline \multicolumn{2}{|l|}{$\begin{array}{l}\text { competitors... Other software for post- } \\
\text { processing has to be investigated.” }\end{array}$} & $\begin{array}{l}\text { 2]. It would not have been enough if we would have } \\
\text { continued with the software we have.” }\end{array}$ \\
\hline Relational uncertainty & N/A \\
\hline No relevant instances & & \\
\hline
\end{tabular}

\section{Table 6: Uncertainty instances Case 2}

\begin{tabular}{|c|c|c|}
\hline Uncertainty instances & Uncertainty description & Uncertainty criticality \\
\hline \multicolumn{2}{|l|}{ Environmental uncertainty } & High criticality \\
\hline $\begin{array}{l}\text { Competitors } \\
\text { uncertainty through } \\
\text { strong increase in } \\
\text { competition }\end{array}$ & $\begin{array}{l}\text { Project manager: " The competition } \\
\text { continues to develop - clearly... Of course } \\
\text { there are those, who offer [another } \\
\text { competitive ES]." }\end{array}$ & $\begin{array}{l}\text { Moderate criticality } \\
\text { Case company needed to follow the market trends to } \\
\text { stay competitive. } \\
\text { Service product manager 1: "Of course this new } \\
\text { 'Zeitgeist' increases the pressure on us because } \\
\text { everyone is doing [ES] now." }\end{array}$ \\
\hline $\begin{array}{l}\text { Customer } \\
\text { uncertainty around the } \\
\text { actual value for the } \\
\text { customer }\end{array}$ & $\begin{array}{l}\text { Project manager: "The customers have } \\
\text { already strongly upgraded [their IT- } \\
\text { security]. They look more closely at what } \\
\text { sort of data leaves [their site] and how, and } \\
\text { what security measures we have. Especially } \\
\text { in the course of the new EU Data Protection } \\
\text { Directive [GDPR]." }\end{array}$ & $\begin{array}{l}\text { High criticality } \\
\text { Without the IT-compliance of the case company, the } \\
\text { ES could not have been offered. } \\
\text { Service product manager } 2 \text { : "IT-compliance is a } \\
\text { huge topic, especially with our larger customers... It } \\
\text { is a large problem and still a very large risk for the } \\
\text { whole project... Because if you don't handle these } \\
\text { network agreements properly, you can't offer the } \\
\text { [ES]." }\end{array}$ \\
\hline \multicolumn{2}{|l|}{ Technical uncertainty } & High criticality \\
\hline $\begin{array}{l}\text { Commercial scoping } \\
\text { uncertainty arising from } \\
\text { attractive and } \\
\text { competitive commercial } \\
\text { scoping }\end{array}$ & $\begin{array}{l}\text { Service product manager } 2: \text { "The } \\
\text { commercial service sales concept for the } \\
\text { product as such was almost bigger than the } \\
\text { product itself... the actual service-level } \\
\text { agreements, and their clustering in different } \\
\text { offerings, that was extremely complex. It } \\
\text { will also be a challenge for our [sales-] } \\
\text { countries." }\end{array}$ & $\begin{array}{l}\text { High criticality } \\
\text { This created s strong time delay due to the high level } \\
\text { of detail required for the precise definition of the } \\
\text { commercial service concept. }\end{array}$ \\
\hline $\begin{array}{l}\text { Modeling and } \\
\text { forecasting } \\
\text { uncertainty about the } \\
\text { forecasting accuracy }\end{array}$ & $\begin{array}{l}\text { IT 2nd level support: "There were the } \\
\text { technical problems. For example the } \\
\text { graphical representation had lines, which } \\
\text { were far too thick so you could not see } \\
\text { anything. These are so many basic things } \\
\text { that you have when you do something like } \\
\text { this for the first time." }\end{array}$ & $\begin{array}{l}\text { Low criticality } \\
\text { Performance forecasting turned out more complex } \\
\text { than anticipated, yet the issues were manageable. } \\
\text { Service product manager } 2: \text { "But the [required] } \\
\text { quality of the [performance forecasting] which will } \\
\text { be delivered to the customer, has been slightly } \\
\text { underestimated." }\end{array}$ \\
\hline $\begin{array}{l}\text { Interfaces with existing } \\
\text { system } \\
\text { uncertainty about the fit } \\
\text { of interfaces with the } \\
\text { existing system }\end{array}$ & $\begin{array}{l}\text { Head of service product management: "If } \\
\text { we go to the [existing software] } \\
\text { landscape... it is not plug and play. There is } \\
\text { a lot of manual work." }\end{array}$ & $\begin{array}{l}\text { Highly criticality } \\
\text { Strong time delay due to interface issues. } \\
\text { Head of service product management: "One of the } \\
\text { reasons we chose [supplier 2] as a partner is that it } \\
\text { should be easy for them to "talk to their own } \\
\text { software". But it seemed not to be that easy... Now } \\
\text { we are talking a substantial delay of more than a } \\
\text { year!" }\end{array}$ \\
\hline $\begin{array}{l}\text { Rollout across the } \\
\text { portfolio } \\
\text { uncertainty arising from } \\
\text { changing requirements } \\
\text { for different machines }\end{array}$ & $\begin{array}{l}\text { Service product manager } 2: \text { "we wanted to } \\
\text { expand it to other [business] areas... And } \\
\text { accordingly we have to bring flexibility into } \\
\text { it... and that get very, very complex and it } \\
\text { has never been there before. [meaning } \\
\text { "been done in-house before"]" }\end{array}$ & $\begin{array}{l}\text { High criticality } \\
\text { High complexity of rollout across the portfolio and } \\
\text { high impact in case of not meeting the specific } \\
\text { requirements of individual products. } \\
\text { Head of service product management: "So we started } \\
\text { with [product 1], we are doing [product } 2 \text { and } \\
\text { product 3] now, and there we see that they all have } \\
\text { different features. And it is very complex but } \\
\text { important to get that right." }\end{array}$ \\
\hline
\end{tabular}




\begin{tabular}{|c|c|c|}
\hline \multicolumn{2}{|l|}{ Organizational uncertainty } & \multirow{2}{*}{$\begin{array}{l}\text { High criticality } \\
\text { Low criticality } \\
\text { This created some complexity and small time delays. } \\
\text { These were however covered and partially resolved } \\
\text { in the course of the large re-organization, which } \\
\text { resulted in the new definition of many processes. }\end{array}$} \\
\hline $\begin{array}{l}\text { Definition of functions } \\
\text { and processes } \\
\text { uncertainty about the } \\
\text { functions and processes } \\
\text { for the execution }\end{array}$ & $\begin{array}{l}\text { Project manager: "Of course there were also } \\
\text { challenges on the whole internal topic. } \\
\text { Which areas are involved and how are our } \\
\text { internal processes? ... who has to do what?" }\end{array}$ & \\
\hline $\begin{array}{l}\text { Pricing } \\
\text { uncertainty about pricing } \\
\text { of the offering in order to } \\
\text { keep it competitive and } \\
\text { profitable }\end{array}$ & $\begin{array}{l}\text { Service product manager } 2: \text { "The pricing } \\
\text { was and is definitely a challenge. Of course } \\
\text { we have a system that continuously collects } \\
\text { data... But the question is how to bundle } \\
\text { that, like going towards value-based } \\
\text { pricing. And there I'm still discussing with } \\
\text { my colleagues how to do that, like what is } \\
\text { the perceived value?" }\end{array}$ & $\begin{array}{l}\text { High criticality } \\
\text { High financial loss in case of wrong pricing. } \\
\text { Service product manager } 2 \text { : "If you commit yourself } \\
\text { for } 10 \text { years and then it goes in the wrong direction, } \\
\text { it can be very expensive... So we are currently still } \\
\text { evaluating the pricing." }\end{array}$ \\
\hline $\begin{array}{l}\text { Reorganization } \\
\text { uncertainty about } \\
\text { organizational and } \\
\text { project impact of the } \\
\text { reorganization }\end{array}$ & $\begin{array}{l}\text { Head of service product management: "In } \\
\text { the meantime the [case company's] } \\
\text { structure changed... So this was an } \\
\text { unexpected hurdle which is still there... } \\
\text { [And now] sometimes people don't have the } \\
\text { skills anymore being in that position." }\end{array}$ & $\begin{array}{l}\text { High criticality } \\
\text { Strong time delay of the project due to loss of } \\
\text { availability of employees for the project. } \\
\text { Head of service product management: "It took away } \\
\text { focus from nearly all people. Because the majority of } \\
\text { the people got a new position or a new working } \\
\text { environment. And that takes time. Until it really } \\
\text { works you are three years further." }\end{array}$ \\
\hline $\begin{array}{l}\text { Long internal processes } \\
\text { uncertainty about the } \\
\text { availability of resources } \\
\text { limited through time } \\
\text { consuming approval } \\
\text { processes }\end{array}$ & $\begin{array}{l}\text { Product launch manager: "There was the } \\
\text { condition from IT side: 'you have to } \\
\text { complete } 5 \text { documents, and only when all } \\
\text { are filled in and approved by } 3 \text { different } \\
\text { boards, then you have our resources.' In } \\
\text { other words, our project plan had to } \\
\text { continuously be moved back because of } \\
\text { course we have planned with the IT } \\
\text { resources." }\end{array}$ & $\begin{array}{l}\text { High criticality } \\
\text { Strong time delay due to inert organizational } \\
\text { processes. } \\
\text { Head of service product management: "We see that } \\
\text { IT has much more to do and in my opinion they are } \\
\text { simply overloaded... but it is the one [issue] where } \\
\text { we have the most struggle and discussions that it } \\
\text { should definitely go faster." }\end{array}$ \\
\hline $\begin{array}{l}\text { Lack of service culture } \\
\text { uncertainty due to } \\
\text { lacking ES acceptance }\end{array}$ & $\begin{array}{l}\text { Product launch manager: "I think in general } \\
\text { the acceptance of [engineering] service is } \\
\text { not as high as it should be...Everyone sees } \\
\text { only the machine as the most important } \\
\text { point." }\end{array}$ & $\begin{array}{l}\text { High criticality } \\
\text { This caused initial struggle and time delay to find } \\
\text { suitable staff for the execution because employees } \\
\text { simply refused to adopt the new ES-related tasks. }\end{array}$ \\
\hline $\begin{array}{l}\text { Overlap with existing } \\
\text { portfolio } \\
\text { uncertainty about the } \\
\text { overlap of offerings }\end{array}$ & $\begin{array}{l}\text { Product launch manager: "Maybe we have } \\
\text { old [engineering-] service products which } \\
\text { can be partially or fully covered with the } \\
\text { new [engineering-] service." }\end{array}$ & $\begin{array}{l}\text { Moderate criticality } \\
\text { This caused a time delay, due to the need to identify } \\
\text { and organize the organically grown portfolio in order } \\
\text { to clearly scope the ES. }\end{array}$ \\
\hline $\begin{array}{l}\text { Project planning } \\
\text { uncertainty of the } \\
\text { estimations made in the } \\
\text { project planning }\end{array}$ & $\begin{array}{l}\text { Service product manager } 2 \text { : "One can } \\
\text { question at the very beginning of the } \\
\text { decision making certain assumptions... } \\
\text { Then you have to create a business case } \\
\text { [based on these assumptions]." }\end{array}$ & $\begin{array}{l}\text { High criticality } \\
\text { Strong delay due to highly increased workload. } \\
\text { Head of service product management: "the whole } \\
\text { project was strongly delayed because there was } \\
\text { much more work to do than expected." }\end{array}$ \\
\hline \multicolumn{2}{|l|}{ Resource uncertainty } & Moderate criticality \\
\hline $\begin{array}{l}\text { Ability to execute the } \\
\text { service } \\
\text { uncertainty about the } \\
\text { responsibility for the } \\
\text { service execution and } \\
\text { training of staff }\end{array}$ & $\begin{array}{l}\text { Head of service product management: "...if } \\
\text { you have no machines in the field yet it is } \\
\text { difficult to get extra manpower for } 2 \text { nd level } \\
\text { [support] which is not called [meaning } \\
\text { demanded] yet" }\end{array}$ & $\begin{array}{l}\text { Low criticality } \\
\text { Some delays because service staff needed to be } \\
\text { trained first. } \\
\text { Service product manager } 1 \text { : "then that led to slight } \\
\text { delays. At the end of the day we got a couple more } \\
\text { people... I handed it over at some point, and I } \\
\text { trained them because it was new territory for them, } \\
\text { and that's why I work closely with them." }\end{array}$ \\
\hline $\begin{array}{l}\text { Resource availability of } \\
\text { specialized knowledge } \\
\text { uncertainty about the } \\
\text { existence and availability } \\
\text { of specialized skills }\end{array}$ & $\begin{array}{l}\text { IT product manager: "But it was a little bit a } \\
\text { problem that [the project manager]... had } \\
\text { never really managed such a project } \\
\text { before... and that was of course very } \\
\text { difficult." }\end{array}$ & $\begin{array}{l}\text { Low criticality } \\
\text { Project depended on expert knowledge but sourced it } \\
\text { through engaging in supplier co-creation. } \\
\text { IT } 2^{\text {nd }} \text { level support: "But for that [ES] you really } \\
\text { need specialists... So then you have to engage with } \\
\text { externals [meaning suppliers] who can develop that } \\
\text { for you." }\end{array}$ \\
\hline
\end{tabular}




\begin{tabular}{|c|c|c|}
\hline $\begin{array}{l}\text { Quality of deliverable } \\
\text { (from suppliers) } \\
\text { uncertainty arising from } \\
\text { the quality of the } \\
\text { partner's deliverable }\end{array}$ & $\begin{array}{l}\text { Service product manager 1: "[supplier 1] } \\
\text { bought the [hardware]. But the hardware } \\
\text { was very faulty. It froze and crashed } \\
\text { always." }\end{array}$ & $\begin{array}{l}\text { High criticality } \\
\text { Strong time delay due to faulty central hardware. } \\
\text { Service product manager } 1 \text { : "It was the [hardware] } \\
\text { from [supplier 1] that was the main problem... but } \\
\text { then we changed to... [supplier } 2 \text { ] and it works fault- } \\
\text { free... If you look for low-cost solutions, which then } \\
\text { don't work, in the end they are expensive because } \\
\text { they cause } 1.5 \text { years of delay, like in our case." }\end{array}$ \\
\hline \multicolumn{2}{|l|}{ Relational uncertainty } & High criticality \\
\hline $\begin{array}{l}\text { Large stakeholder } \\
\text { network } \\
\text { uncertainty through } \\
\text { coordination of large } \\
\text { stakeholder network }\end{array}$ & $\begin{array}{l}\text { Head of service product management: "I } \\
\text { think the more stakeholders you have in the } \\
\text { project, the more individual roadmaps you } \\
\text { have too." }\end{array}$ & $\begin{array}{l}\text { Moderate criticality } \\
\text { This created complexity in project coordination and } \\
\text { months delay due to continuously aligning all the } \\
\text { stakeholders and their own schedules with the needs } \\
\text { of the development project. }\end{array}$ \\
\hline $\begin{array}{l}\text { Conflict resolution with } \\
\text { supplier } \\
\text { uncertainty arising from } \\
\text { conflict resolution }\end{array}$ & $\begin{array}{l}\text { Service product manager 1: "Their } \\
\text { [hardware] was faulty... so we had to } \\
\text { escalate... but we did not want to lose } \\
\text { [supplier 1] and they did not want to lose }\end{array}$ & $\begin{array}{l}\text { High criticality } \\
\text { High impact in case of harmed relationship with the } \\
\text { supplier due to additional project-external } \\
\text { engagement with the supplier: Need to find a } \\
\text { balance of escalation and collaboration. } \\
\text { IT } 2^{\text {nd }} \text { level support: "managing that relationship was } \\
\text { very difficult... but it was not a showstopper [for the } \\
\text { project] because there were alternatives to [supplier } \\
\text { 1]." }\end{array}$ \\
\hline $\begin{array}{l}\text { Hidden agendas of } \\
\text { suppliers } \\
\text { uncertainty arising from } \\
\text { hidden agendas }\end{array}$ & $\begin{array}{l}\text { Technical project manager (from supplier } \\
\text { 2): "It is always a fine line since we offer } \\
\text { standard software. And then difficulties } \\
\text { with customer-specific requirements [of } \\
\text { case company 2] arise." } \\
\text { Service Product Manager 1:"But that's } \\
\text { basically the problem because... the } \\
\text { requirements were just not fulfilled [by } \\
\text { supplier 2]." }\end{array}$ & $\begin{array}{l}\text { High criticality } \\
\text { Strong and continuous time delay due to unmet } \\
\text { delivery agreements with the supplier. } \\
\text { IT product manager: "[supplier 2] did not meet the } \\
\text { agreed development deadlines. So we could only } \\
\text { express wishes of what we would have liked to have } \\
\text { included in the next update. And then they always } \\
\text { that it will not be included in the upcoming update, } \\
\text { but in the one on half a year or a year. So this } \\
\text { naturally delayed us a lot because we had to wait for } \\
\text { them to finish." }\end{array}$ \\
\hline $\begin{array}{l}\text { Supplier capabilities } \\
\text { uncertainty about the } \\
\text { knowledge and ability of } \\
\text { supplier }\end{array}$ & $\begin{array}{l}\text { IT 2nd level support: "For [supplier 2] that } \\
\text { was the first project like that, they've never } \\
\text { done that before. And that was noticeable... } \\
\text { they had to learn a lot." }\end{array}$ & $\begin{array}{l}\text { High criticality } \\
\text { Strong time delay due to the long learning phase of } \\
\text { the supplier. } \\
\text { IT } 2^{\text {nd }} \text { level support: "They said that they chose } \\
\text { [supplier 2] because it is a large partner and we } \\
\text { already had their products in-house. The expectation } \\
\text { was that it would be easier to implement it internally } \\
\text { [because they had to embed the software in the IT } \\
\text { landscape of supplier 2]. And they were apparently } \\
\text { aware of the learning phase of [supplier } 2 \text { ]. But on } \\
\text { the other hand, it seems that they underestimated } \\
\text { really how long this learning phase lasted." }\end{array}$ \\
\hline $\begin{array}{l}\text { Supplier } \\
\text { communication } \\
\text { uncertainty through } \\
\text { native and vernacular } \\
\text { language issues }\end{array}$ & $\begin{array}{l}\text { Head of service product management: "It is } \\
\text { not always easy to speak the same language. } \\
\text { IT guys and business guys are - first of all, } \\
\text { they were not all German speakers of } \\
\text { course. Then you have to work in a non- } \\
\text { native language... Second, there was a lot of } \\
\text { remote communication, which is not always } \\
\text { that easy. And third, they think different, } \\
\text { they have a different, not attitude but, IT } \\
\text { language is not always business language } \\
\text { and the other way around." }\end{array}$ & $\begin{array}{l}\text { High criticality } \\
\text { Strong time delay due to misunderstandings arising } \\
\text { from vernacular language issues among the } \\
\text { collaborating parties. } \\
\text { Service product manager 1: "It was completely new } \\
\text { territory for them [meaning supplier 2]. And then of } \\
\text { course it took a long time until they understood what } \\
\text { we wanted. That also delayed a lot, I have to say } \\
\text { honestly. I find that much more critical [than the } \\
\text { faulty hardware of supplier 1]." }\end{array}$ \\
\hline
\end{tabular}

